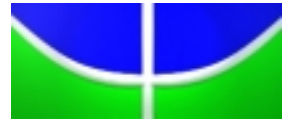 \\ UNIVERSIDADE DE BRASÍLIA
}

Faculdade de Economia, Administração, Contabilidade e Ciência da Informação e Documentação

Programa de Pós-Graduação em Administração

Curso de Especialização em Gestão de Pessoas

\section{FATORES DE ADOECIMENTO NAS ÁREAS COMPARTILHADAS DO SISTEMA INDÚSTRIA}

Ludmilla de Sá Moraes Telles Silva

Brasília - DF 


\section{UNIVERSIDADE DE BRASÍLIA}

Faculdade de Economia, Administração, Contabilidade e Ciência da Informação e Documentação

Programa de Pós-Graduação em Administração

Curso de Especialização em Gestão de Pessoas

\section{FATORES DE ADOECIMENTO NAS ÁREAS COMPARTILHADAS DO SISTEMA INDÚSTRIA}

Ludmilla de Sá Moraes Telles Silva

Monografia apresentada ao Programa de PósGraduação, da Faculdade de Economia, Administração, Contabilidade e Ciência da Informação e Documentação (FACE), da Universidade de Brasília, como requisito parcial à obtenção do grau de Especialista em Gestão de Pessoas.

Orientadora $\operatorname{Prof}^{\mathrm{a}} \mathrm{Dr}^{\mathrm{a}}$. Ana Magnólia Mendes.

Brasília - DF 


\section{AGRADECIMENTOS}

Agradeço a minha família, em especial ao meu marido e ao meu filho, por me apoiarem durante todo o projeto, a minha orientadora por me mostrar a essência da Qualidade de Vida no Trabalho e a Carla Dutra por estimular a aprendizagem contínua. 
Trabalho é a atividade manifestada por homens e mulheres para realizar o que ainda não está prescrito pela organização do trabalho.

Christophe Dejours 


\section{RESUMO}

Este estudo investiga o processo de saúde-adoecimento dos profissionais das áreas compartilhadas das Entidades Nacionais do Sistema Indústria - Confederação Nacional da Indústria - CNI, Serviço Social da Indústria/Departamento Nacional - SESI/DN, Serviço Nacional de Aprendizagem Industrial/Departamento Nacional - SENAI/DN e Instituto Euvaldo Lodi/Núcleo Central - IEL/NC, com base nos referenciais teóricos de qualidade de vida no trabalho, da psicodinâmica do trabalho e da ergonomia da atividade. Busca-se levantar qual o tipo de sofrimento eles estão expostos, uma vez que o ser humano pode se submeter a um esforço físico além do suportável, sem necessariamente sofrer danos físicos. A má qualidade nas relações, a falta de reconhecimento e de cooperação, a fragmentação e rigidez da organização do trabalho também causam sofrimento. O trabalho é estudado em 4 (quatro) dimensões: contexto de trabalho, custo humano de trabalho, custo de prazersofrimento no trabalho e danos relacionados ao trabalho. Com base nos resultados foram identificados os fatores do processo de saúde e adoecimento dos profissionais das áreas compartilhadas do Sistema Indústria. Percebeu-se que a organização do trabalho e as relações socioprofissinais são vistas como críticas, como também os danos físicos. Sugere-se a manutenção do programa Qualidade de Vida atual implantando-se algumas ações de melhoria na diretriz "saúde preventiva".

Palavras-chave: Profissionais do Sistema Indústria. Prazer-sofrimento. Qualidade de Vida no Trabalho. 


\section{LISTA DE FIGURAS}

Figura 1 - Metas do Programa Qualidade de Vida (2002). Fonte: Sistema Indústria (2002).. 38

Figura 2 - Número participantes PAQV. Fonte: Sistema Indústria (2005) 39

\section{LISTA DE GRÁFICOS}

Gráfico 1: Resultado PCMSO 2005. Fonte: Sistema Indústria 40

Gráfico 2 - Escala de Avaliação do Contexto de Trabalho....................................................... 44

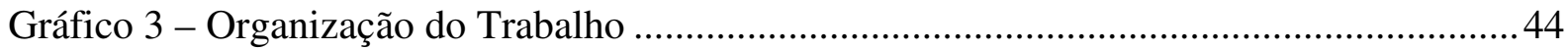

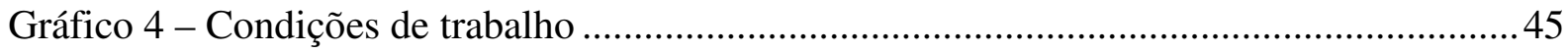

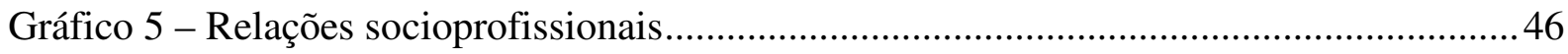

Gráfico 6: Escala de Custo Humano do Trabalho ....................................................................... 48

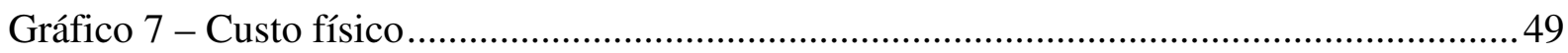

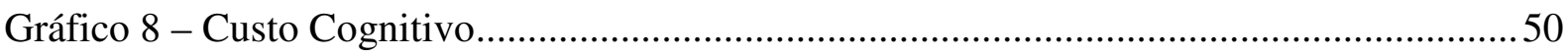

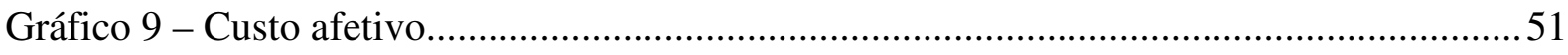

Gráfico 10 - Escala de Indicadores de Prazer-Sofrimento no Trabalho - PRAZER .................54

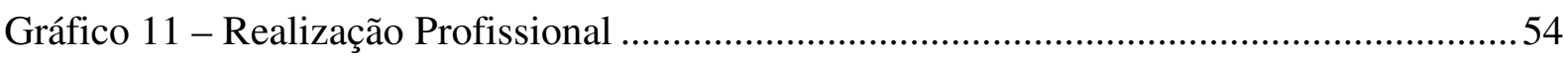

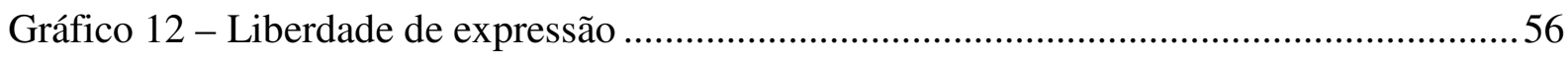

Gráfico 13 - Escala de Indicadores de Prazer-Sofrimento no Trabalho - SOFRIMENTO .....57

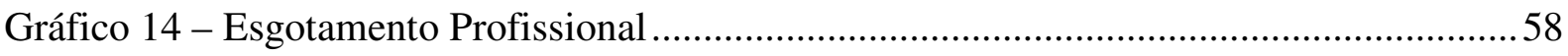

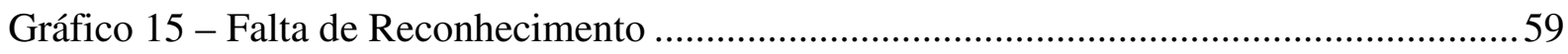

Gráfico 16: Escala de Avaliação dos Danos Relacionados ao Trabalho.................................. 61

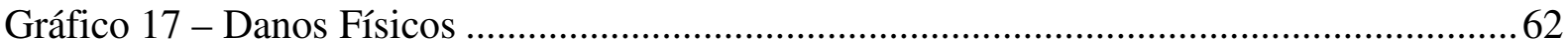

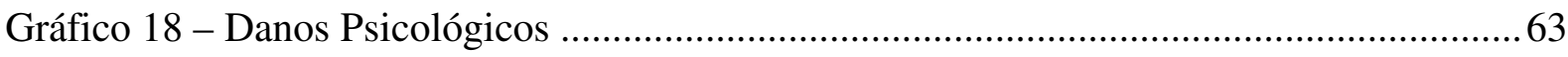

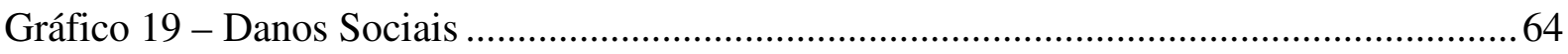




\section{LISTA DE TABELAS}

Tabela 1 - Freqüência de respostas para o campo "gênero"

Tabela 2 - Frequiência de respostas para o campo "escolaridade

Tabela 3 - Freqüência de respostas para o campo "estado civil". 34

Tabela 4 - Freqüência de respostas para o campo "faixa etária". 34

Tabela 5 - Frequiência de respostas para o campo "tempo de serviço na Instituição".. 34

Tabela 6 - Frequiência de respostas para o campo "tempo de serviço no cargo". 35

Tabela 7 - Frequiência de respostas para o campo "cargo atual". 35

Tabela 8 - Organização do Trabalho: Itens mais satisfatórios. 45

Tabela 9 - Organização do Trabalho: Itens mais graves. 45

Tabela 10 - Condições de Trabalho: Itens mais satisfatórios .46

Tabela 11 - Condições de Trabalho: Item crítico. 46

Tabela 12- Relações Socioprofissionais: Itens mais satisfatórios.

Tabela 13 - Relações Socioprofissionais: Itens mais críticos 47

Tabela 14 - Custo Físico: Itens mais satisfatórios 49

Tabela 15 - Custo Físico: Itens mais críticos 50

Tabela 16 - Custo Cognitivo: Item mais satisfatório 50

Tabela 17 - Custo Cognitivo: Itens mais graves 51

Tabela 18 - Custo Afetivo: Itens mais satisfatórios 52

Tabela 19 - Custo Afetivo: Itens mais graves 52

Tabela 20 - Realização Profissional: Itens mais satisfatórios 55

Tabela 21 - Realização Profissional: Itens mais críticos 55

Tabela 22 - Liberdade de Expressão: Itens mais satisfatórios 56

Tabela 23 - Liberdade de Expressão: Itens menos satisfatórios 56 
Tabela 24 - Esgotamento Profissional: Itens mais satisfatórios.............................................58

Tabela 25 - Esgotamento Profissional: Itens menos satisfatórios..........................................58

Tabela 26 - Falta de Reconhecimento: Itens mais satisfatórios ..............................................59

Tabela 27 - Falta de Reconhecimento: Itens menos satisfatórios ..........................................60

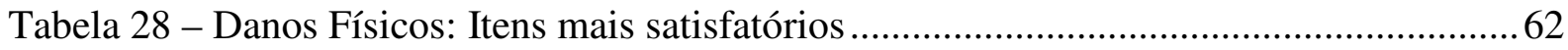

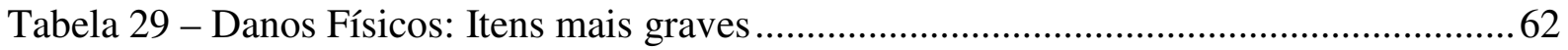

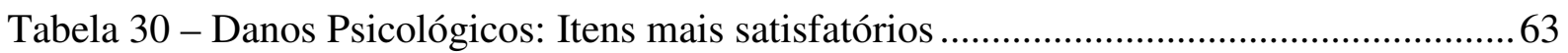

Tabela 31 - Danos Psicológicos: Itens mais críticos.......................................................... 63

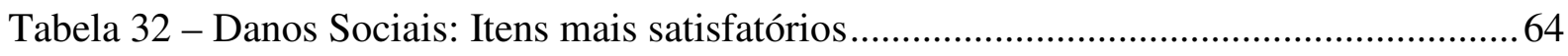

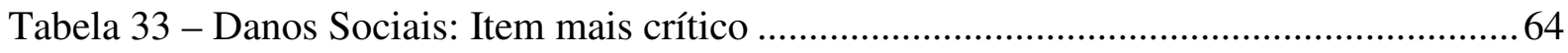




\section{SUMÁRIO}

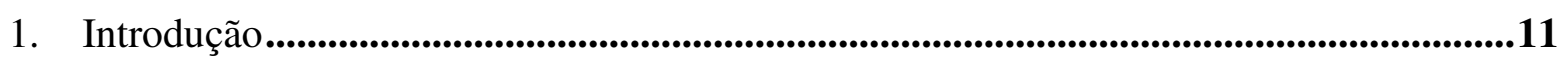

1.1. Formulação do problema de pesquisa .......................................................................................13

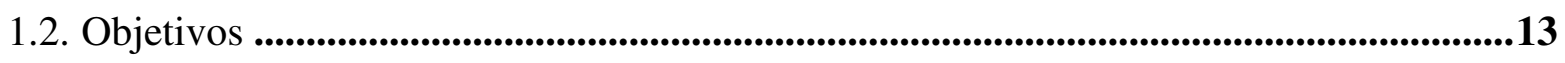

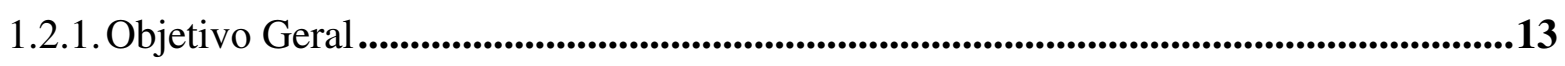

1.2.2. Objetivos Espefícios.....................................................................................................14

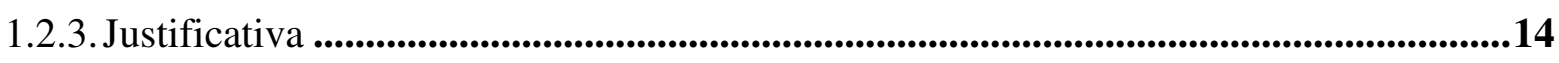

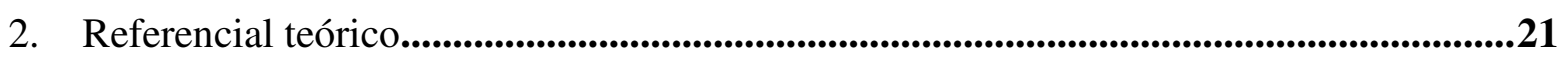

2.1. Conceituação de qualidade de vida no trabalho ..........................................................21

2.2. A Psicodinâmica do Trabalho ...........................................................................................26

2.3. A Ergonomia da Atividade..................................................................................................................29

2.4. O diálogo entre ergonomia da atividade e psicodinâmica do trabalho...............................30

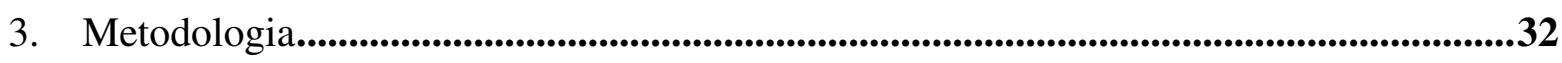

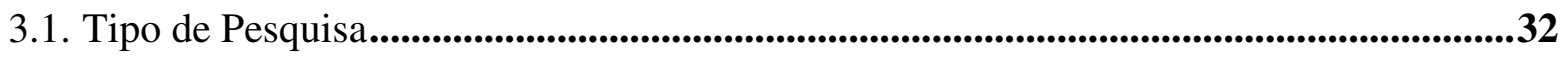

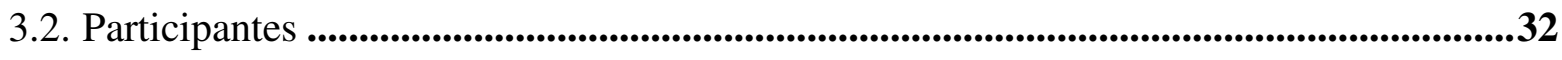

3.3. Instrumento ....................................................................................................................................35

3.4. Histórico do Programa Qualidade de Vida do Sistema Indústria......................................36

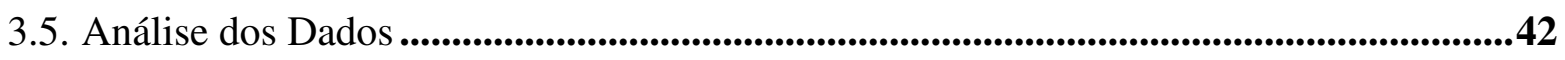

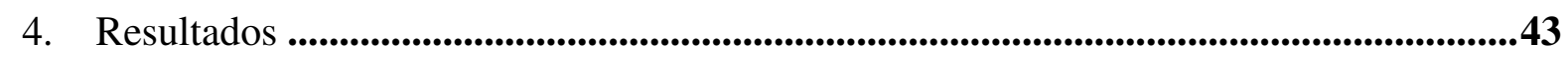

4.1. Resultado da Escala de Avaliação do Contexto de Trabalho (EACT) .................................43

4.1.1. Organização do trabalho ..................................................................................................44

4.1.2. Condições de Trabalho...................................................................................45

4.1.3. Relações Socioprofissionais ...............................................................................46

4.2. Resultado da Escala de Custo Humano do Trabalho (ECHT) ........................................48

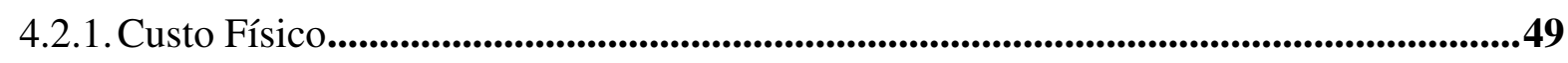




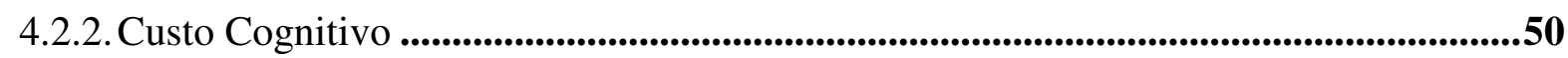

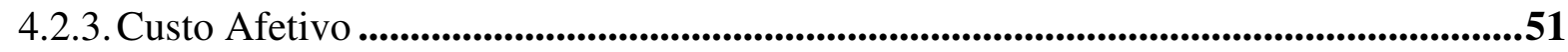

4.3. Resultado da Escala de Indicadores de Prazer e Sofrimento no Trabalho (EIPST)........52

4.3.1. Vivências de Prazer................................................................................................................53

4.3.1.1.Realização Profissional ...................................................................................................54

4.3.1.2.Liberdade de Expressão........................................................................................55

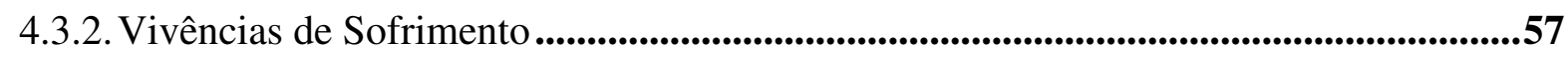

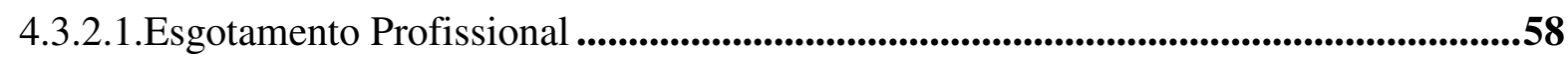

4.3.2.2.Falta de Reconhecimento....................................................................................59

4.4. Resultado da Escala de Avaliação dos Danos Relacionados ao Trabalho (EADRT) .....60

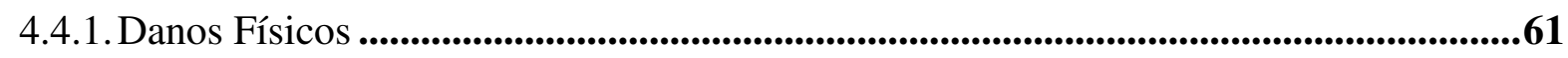

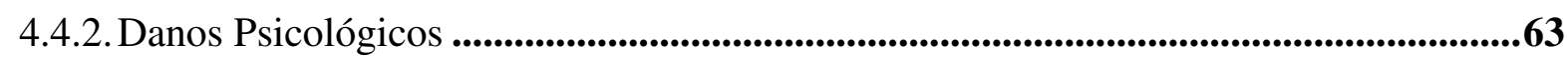

4.4.3. Danos Sociais .................................................................................................................................64

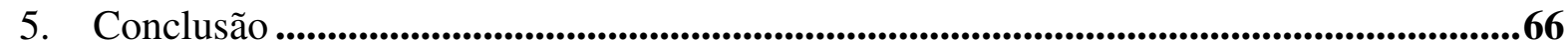

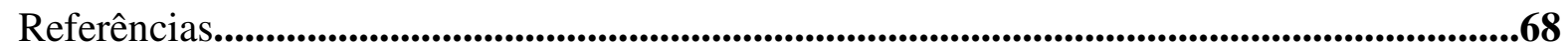

Apêndice A................................................................................................................................................................70

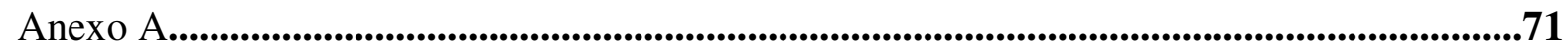




\section{Introdução}

$\mathrm{O}$ atual contexto social e econômico caracteriza-se por demandar de grande parte das empresas uma crescente atenção com seus ativos intangíveis. Há algumas décadas, a competitividade de várias organizações estava ligada ao tamanho e complexidade de sua estrutura física. Hoje, aspectos como o conhecimento nelas desenvolvido e mantido, sua marca e valorização no mercado, e as pessoas que nelas trabalham podem se tornar diferenciais competitivos mais importantes do que os aspectos tangíveis.

Nesta sociedade que Drucker (2000) chama de "Sociedade do Conhecimento", a internacionalização dos mercados e as pressões por produtividade e capacidade competitiva que as empresas vêm sofrendo, tornam cada vez maiores as demandas de produtividade, iniciativa, conhecimento e inovação sobre as pessoas. Estas sentem cada vez mais os efeitos de um novo ambiente de trabalho, onde se exige muito dos profissionais. Assim, segundo Oliveira e Limongi-França (2005), a Qualidade de Vida no Trabalho passa a ser uma preocupação cada vez mais presente nas organizações.

Estudos na área de qualidade de vida no trabalho têm abordado o tema do sofrimento psíquico nas organizações em suas múltiplas facetas.

A palavra "trabalho" vem do latim e significa tripalium - espécie de tortura. Isso também transmite uma noção de dor e sofrimento. No entanto, Freud diz que é pelo trabalho que o homem se reinventa e se supera. Isso trouxe uma nova dimensão sobre a importância do trabalho como papel fundamental para o equilíbrio do homem, para sua saúde física e mental, bem como inserção no meio social.

Segundo Limongi-França, (2004), ao realizar um trabalho, o indivíduo está inserido num contexto social mais amplo, não se limitando ao escopo do cargo ou da tarefa, a representação que o trabalho tem socialmente causa impacto na vida e no bem-estar desse indivíduo, podendo levar a situações de maior ou menor desgaste.

Estudo das relações dinâmicas entre a organização do trabalho e os processos de subjetivação é, conforme Mendes (2007), o objeto de psicodinâmica do trabalho. De acordo com esta autora, esses processos se manifestam nas vivências de prazer-sofrimento, nas estratégias de ação para mediar às contradições, nas patologias sociais, na saúde e no adoecimento. 
Segundo Freitas (2006) é necessário um tratamento interdisciplinar da saúde no trabalho a fim de entender a complexidade dos atuais contextos de trabalho, nos quais vivenciam-se novas formas de gestão da força de trabalho.

A psicodinâmica do trabalho investiga a saúde no trabalho e tem como ponto central de análise o sofrimento e as estratégias de mediação utilizadas pelos trabalhadores para ressignificar e superar o sofrimento, com vistas à transformação do contexto de trabalho em um lugar de prazer (Ferreira; Mendes, 2003).

Para Dejours, podemos descrever a psicodinâmica do trabalho, como sendo o estudo da análise das estratégias de defesa individuais e coletivas contra o sofrimento e a doença mental do trabalho. O que é explorado pela organização não é o sofrimento, mas principalmente as estratégias de mediação utilizadas contra esse sofrimento, tais como: proteção, adaptação e exploração (Mendes, 2007).

As defesas de proteção são modos de pensar, sentir e agir compensatórios, que podem evitar o adoecimento por meio da alienação das causas do sofrimento.

As defesas de adaptação e exploração têm nas suas bases a negação do sofrimento e a submissão ao desejo da produção. Porém, elas podem se esgotar mais rapidamente porque exigem do trabalhador um investimento físico e sociopsíquico além dos desejos e capacidades dele.

O contexto de trabalho no qual o trabalho se realiza é composto pela organização do trabalho, as condições de trabalho e as relações socioprofissionais. O contex to de trabalho nas suas três dimensões influencia o prazer e o sofrimento, que são constitutivos da subjetividade do trabalho. Para a abordagem psicodinâmica, o prazer no trabalho torna-se uma conquista constante e, ao mesmo tempo, fortalece a sua identidade pessoal, quando tem contato com a produção e com as pessoas que fazem parte das socializações da vida do sujeito trabalhador.

Para Freitas (2006), o trabalho não necessariamente consegue ser fonte de prazer; muitas vezes torna-se algo penoso e doloroso, causando sofrimento para os trabalhadores. Tal sofrimento origina-se das condições de trabalho, da organização deste e das relações socioprofissionais que restringem a plena realização do homem, a sua liberdade - expressão de subjetividade e identidade.

O sofrimento é vivenciado em uma realidade que não oportuniza possibilidades de ajustamento das necessidades do trabalhador, em função das imposições e pressões do contexto de trabalho, e também não se instala de maneira constante. 
Segundo Ferreira e Mendes (2003), o custo humano do trabalho, conceito fundamental da ergonomia da atividade, representa o dispêndio dos trabalhadores nas esferas físicas, cognitivas e afetivas presentes no contexto de trabalho que obstaculizam e desafiam a inteligência dos trabalhadores.

A ergonomia da atividade estuda a relação entre os trabalhadores e o contexto de trabalho, busca compreender os indicadores críticos que surgem no contexto de trabalho, com vistas a transformá-los, a partir de uma solução de compromisso que envolva os objetivos dos trabalhadores, gestores e consumidores. (Ferreira; Mendes, 2003).

A relação entre trabalho, custo humano, prazer, sofrimento constitui fatores de risco para o adoecimento que podem gerar danos físicos e psicossociais na vida dos trabalhadores, dependendo do sucesso ou fracasso do uso das estratégias de mediação individual e coletiva do sofrimento e do custo humano negativo. Tais danos surgem em função de um sofrimento freqüente e intenso, e da utilização fracassada das estratégias de mediação individual e coletiva.

\subsection{Formulação do problema de pesquisa}

Quais são os fatores que podem levar os profissionais da área compartilhada do Sistema Indústria ao adoecimento?

\subsection{Objetivos}

\subsubsection{Objetivo Geral}

O objetivo geral deste estudo é identificar os fatores que determinam o processo de saúde-adoecimento dos profissionais das áreas compartilhadas do Sistema Indústria. 


\subsubsection{Objetivos Específicos}

Como objetivos específicos, pretende-se nesta monografia:

- Diagnosticar os riscos de adoecimento no trabalho a partir do contexto de trabalho;

- Diagnosticar os riscos de adoecimento no trabalho a partir do custo humano de trabalho;

- Diagnosticar os riscos de adoecimento no trabalho a partir do custo prazer e sofrimento no trabalho;

- Diagnosticar os riscos de adoecimento no trabalho a partir dos danos relacionados ao trabalho; $\mathrm{e}$

- Subsidiar o planejamento de ações institucionais para manutenção e/ou melhoria do Programa Qualidade de Vida no Trabalho a partir do diagnóstico realizado.

\subsubsection{Justificativa}

O objeto deste estudo é conhecer o nível de qualidade de vida no trabalho dos profissionais das áreas compartilhadas do Sistema Indústria, busca-se entender qual o tipo de sofrimento eles estão expostos, uma vez que o ser humano pode se submeter a um esforço físico além do suportável, sem necessariamente sofrer danos físicos. A má qualidade nas relações, a falta de reconhecimento e de cooperação, a fragmentação e rigidez da organização do trabalho também causam sofrimento.

O Sistema Indústria promove a articulação do setor industrial brasileiro em torno das grandes questões nacionais, buscando a excelência e a inovação do parque fabril para garantir o crescimento sustentado do País. É formado pela Confederação Nacional da Indústria - CNI, o Serviço Social da Indústria/Departamento Nacional - SESI/DN, o Serviço Nacional de Aprendizagem Industrial/Departamento Nacional - SENAI/DN e o Instituto Euvaldo Lodi/Núcleo Central - IEL/NC. A sua missão é promover a competitividade da Indústria Brasileira influenciando a criação de um ambiente favorável aos negócios e estimulando o desenvolvimento humano e tecnológico. 
Os valores e princípios do Sistema Indústria são: livre iniciativa, ética, transparência, satisfação dos clientes, alta performance e valorização das pessoas.

O objetivo estratégico referente ao Capital Humano é "adequar a gestão de pessoas para assegurar o desenvolvimento e a valorização de competências, com foco em resultados e na atração e retenção de talentos" (CNI, 2006, p.37).

Líder do setor industrial brasileiro, o Sistema Indústria desenvolve atividades de excelência em formação profissional, inovação tecnológica, responsabilidade social e desenvolvimento empresarial. Sua rede de escolas, laboratórios e centros tecnológicos espalhada por todo o território nacional presta serviços de qualidade que ajudam a indústria a desenvolver produtos inovadores e a superar os desafios do mundo globalizado.

As missões das quatro entidades nacionais são distintas:

\section{- CNI: defesa dos interesses da indústria}

A Confederação Nacional da indústria - CNI é o órgão máximo de representação formal do setor industrial. Congrega 27 Federações de Indústria dos Estados e do Distrito Federal, às quais estão filiados mais de mil sindicatos patronais. Desde que foi fundada, em 1938, defende os interesses e busca a convergência do empresariado nas grandes questões nacionais, principalmente naquelas que têm impacto sobre a produtividade $\mathrm{e}$ a competitividade das empresas.

Apoiada em estudos, avaliações técnicas, consultas às empresas e com o suporte de seus dez conselhos temáticos e do Fórum Nacional da Indústria, a CNI formula propostas para estimular a competitividade da indústria brasileira.

\section{- SESI: qualidade de vida no trabalho}

O Serviço Social da Indústria - SESI é o grande gestor das políticas de responsabilidade social do setor produtivo. Dotado de ampla estrutura de educação básica, saúde, esporte, lazer e cultura, oferece diversos programas que visam melhorar a qualidade de vida dos trabalhadores e de suas famílias.

Todos esses projetos resultam em ganhos de produtividade para as empresas. A abrangência das ações educacionais, desenvolvidas em benefício dos filhos dos industriários e da comunidade, faz do SESI a maior rede de ensino particular do País. Pautado por um 
projeto pedagógico que privilegia a criatividade e a inovação, atua em programas de alfabetização e educação formal de nível Fundamental e Médio para jovens e adultos que não tiveram a oportunidade de escolarização na idade apropriada.

Além disso, mantém cursos de extensão e pós-graduação para pessoas interessadas em acompanhar as constantes transformações do mundo do conhecimento, ministrados pela Universidade Corporativa do SESI - UniSESI com mais de 2.200 unidades espalhadas em cerca de 1.600 municípios brasileiros, e convênios com organismos multilaterais, como a Unesco, instituições estrangeiras e órgãos do governo brasileiro.

O SESI desenvolve, desde 1946, inúmeros projetos de saúde, que envolvem principalmente a prevenção de doenças e a segurança no ambiente de trabalho. Programas nas áreas de esporte, lazer e cultura valorizam os talentos, estimulam a integração dos trabalhadores e promovem a cidadania e o bem-estar nas empresas, nas famílias e nas comunidades.

\section{- SENAI: educação profissional e inovação}

O Serviço Nacional de Aprendizagem Industrial - SENAI é o maior complexo de Educação Profissional da América Latina. Criado em 1942 com o compromisso de qualificar os trabalhadores brasileiros, oferece cursos de aprendizagem, aperfeiçoamento técnico, de nível superior e pós-graduação em 28 áreas tecnológicas, que atendem desde as necessidades de microempreendimentos até às demandas de grandes conglomerados industriais.

A estrutura educacional do SENAI, presente em todo o País, inclui 396 escolas fixas, 369 unidades móveis e 320 kits do Programa de Ações Móveis - PAM equipados para a realização de cursos rápidos, principalmente entre comunidades de baixa renda.

Essas unidades, que dispõem de modernas tecnologias, atendem a cerca de 2 milhões de pessoas ao ano e integram uma rede de conhecimentos que abre oportunidades de qualificação para jovens e adultos ao longo de toda a vida produtiva.

Além das unidades de formação profissional, o SENAI oferece às indústrias os serviços de 57 Centros Tecnológicos, especializados na produção, adaptação e disseminação de estratégias e produtos inovadores. Mantém, ainda, uma rede de laboratórios que prestam serviços de calibração, ensaios, certificação e desenvolvimento de produtos. Em parceria com 
instituições e organizações nacionais, internacionais, além de diversos países, o SENAI desenvolve soluções para acelerar a modernização da gestão e dos processos de produção nas empresas brasileiras.

\section{- IEL: conhecimento aplicado à produção}

O Instituto Euvaldo Lodi (IEL) promove a competitividade e o desenvolvimento industrial por meio da capacitação empresarial, do suporte à inovação de produtos e processos, e de programas de desenvolvimento regional e de cooperação internacional.

Criado em 1969, o IEL desenvolve programas de capacitação empresarial, com o apoio das melhores universidades do Brasil e do mundo. O objetivo é desenvolver competências organizacionais, proporcionando às empresas vantagens competitivas necessárias para enfrentar desafios impostos pelo mercado global. Além disso, o IEL oferece programas de estágios e bolsas educacionais, que contribuem para a formação de talentos e transferência de conhecimento das universidades para as empresas.

O IEL apóia o desenvolvimento de setores, cadeias e arranjos produtivos da indústria, incentivando a inovação tecnológica e o dinamismo da atividade empresarial em diversas regiões brasileiras. Mantém a Rede de Tecnologia - RETEC, que atua na intermediação de difusão de informações e de serviços tecnológicos.

A inserção internacional das empresas é uma estratégia fundamental para o crescimento empresarial brasileiro. Neste sentido, o IEL realiza rodadas de negócios, missões empresariais e programas de capacitação que permitem às empresas estarem preparadas para competir no espaço econômico global. Uma das grandes iniciativas é o programa ALInvest, da Comissão Européia, que promove o intercâmbio de informações e cooperação com empresas latino-americanas e européias.

Em 2003, o Sistema Indústria passou por uma mudança na sua estrutura organizacional, na qual foram criadas as chamadas áreas de serviços compartilhados e as unidades corporativas, visando obter os "chamados" ganhos de produção e conseqüentemente melhorar os resultados financeiros.

As áreas compartilhadas e unidades corporativas são consideradas como áreas/unidades que suportam as atividades de negócio, as chamadas áreas meio, nos assuntos referentes à administração, recursos humanos, financeiros, tecnologia da informação, dentro 
outras e são compostas por:

- As áreas de serviços compartilhados: Tecnologia da Informação, Finanças, Administração, Arrecadação, Documentação e Informação, Recursos Humanos e Convênios.

- As unidades corporativas: Planejamento Orçamento e Gestão, Comunicação Social, Auditoria e Superintendência Jurídica.

A Área Compartilhada de Recursos Humanos tem dentre as suas atribuições e responsabilidades: realizar programas de promoção da qualidade de vida para os colaboradores das Entidades Nacionais; assessorar Federações, Departamentos Regionais do SESI e SENAI e Núcleos Regionais do IEL em assuntos relacionados a Recursos Humanos e aplicar e disseminar a legislação pertinente, no âmbito de sua competência, com o apoio da Unidade Jurídica.

Hoje, as Entidades Nacionais do Sistema Indústria, contam com aproximadamente 850 colaboradores, entre funcionários, estagiários e prestadores de serviço terceirizados.

Para conhecer o nível de qualidade de vida no trabalho dos profissionais das áreas compartilhadas do Sistema Indústria, será aplicado o ITRA - Inventário de Trabalho e Riscos de Adoecimento, que é um instrumento de pesquisa estruturado e validado, com objetivo de traçar um perfil dos antecedentes, medidores e efeitos do trabalho no processo de adoecimento e subsidiar a construção do planejamento de ações institucionais nos campos das condições, organização e relações socioprofissionais de trabalho.

O objeto de investigação foi construído a partir do diálogo entre a psicodinâmica do trabalho e a ergonomia da atividade, sobretudo das novas categorias conceituais propostas pelo diálogo entre as duas disciplinas.

Segundo Ferreira e Mendes (2003), o trabalho é visto como estruturante psíquico e como uma atividade preponderantemente humana, de caráter intencional, finalístico e perpassado pela cultura. Tem como funções a busca de sobrevivência e a auto-realização. O trabalho, quando não proporciona ao trabalhador a garantia de sobrevivência e a construção de sua identidade, pode resultar no aparecimento do sofrimento. Este, se não for enfrentado adequadamente, pode levar ao adoecimento.

A saúde é compreendida, conforme definição proposta por Ferreira e Mendes (2003), como sendo um processo de busca permanente dos trabalhadores pela integridade física, 
psíquica e social nos contextos de trabalho (CT). Para os pesquisadores, a saúde se viabiliza a medida que os trabalhadores conseguem utilizar as estratégias de mediação individual e coletiva para dar conta das diversidades do contexto de trabalho.

O contexto de trabalho (CT) no qual o trabalho é realizado se caracteriza pela organização, condições e relações de trabalho, conforme estudo realizado por Ferreira e Mendes (2003).

Segundo os autores, a organização do trabalho é constituída pelos elementos prescritos (formal ou informalmente) que expressam as concepções e as práticas de gestão de pessoas e do trabalho presentes no lócus de produção e balizam o seu funcionamento, conforme os seguintes elementos:

- divisão do trabalho: hierárquica, técnica, social;

- produtividade esperada: metas, qualidade, quantidade;

- regras formais: missão, normas, dispositivos jurídicos, procedimentos;

- tempo: duração da jornada, pausas e turnos;

- controles: supervisão, fiscalização e disciplina;

- ritmos: prazos e tipos de pressão;

- características das tarefas: natureza e conteúdo.

As condições de trabalho são constituídas pelos elementos estruturais que expressam as condições de trabalho presente no lócus de produção e caracterizam sua infra-estrutura, apoio e práticas administrativas. Os seguintes elementos integram essa dimensão:

- ambiente físico: sinalização, espaço, ar, luz, temperatura, som;

- instrumentos: ferramentas, máquinas, documentação;

- equipamentos: materiais arquitetônicos, aparelhagem, mobiliário;

- matéria-prima: objetos materiais/simbólicos, informacionais;

- suporte organizacional: remuneração, desenvolvimento de pessoal e benefícios.

As relações socioprofissionais são constituídas pelos elementos interacionais que expressam as relações socioprofissionais presentes no lócus de produção e caracterizam sua dimensão social. Os elementos que integram essa dimensão são os seguintes:

- interações hierárquicas: chefias superiores;

- interações coletivas intra e intergrupos: membros da equipe de trabalho, membros de outros grupos de trabalho, e

- interações externas: usuários, consumidores, representantes institucionais. 
O trabalhador, em seu fazer cotidiano, recebe um custo humano e, ao mesmo tempo, reage a esse custo. Para Ferreira e Mendes (2003), o contexto de trabalho é um espaço de complexidade em função do confronto entre o que é específico desse contexto e as competências individual e coletiva dos trabalhadores. Deste modo, o CT, ao produzir um custo humano, pode predominar o sofrimento. Este pode gerar estratégias de mediação individual ou coletiva (EMIC), as quais são alternativas para lidar com o sofrimento no trabalho e o custo humano negativo. 


\section{Referencial teórico}

Quanto à expressão Qualidade de Vida no Trabalho - QVT, não se pode atribuir uma definição consensual, devido a várias revisões bibliográficas sobre o tema. O conceito engloba o atendimento, as necessidades e aspirações humanas, calcadas na idéia de humanização do trabalho e na responsabilidade sociais da empresa. Nesse item serão destacados, com base na literatura, alguns aspectos teóricos e conceituais relativos ao tema Qualidade de Vida no Trabalho - QVT.

\subsection{Conceituação de qualidade de vida no trabalho}

Segundo Limongi-França e Arellano (2002) existem muitas interpretações de qualidade de vida no trabalho, desde o foco clínico da ausência de doenças no âmbito pessoal até as exigências de recursos, objetos e procedimentos de natureza gerencial e estratégica no nível das organizações.

Segundo Seidl e Zannon (2004) na área da saúde, o interesse pelo conceito de Qualidade de Vida no Trabalho é relativamente recente e decorre, em parte, dos novos paradigmas que têm influenciado as políticas e as práticas do setor nas últimas décadas. Os determinantes e condicionantes do processo saúde-doença são multifatoriais e complexos. Assim, saúde e doença configuram processos compreendidos como um continuum, relacionados aos aspectos econômicos, socioculturais, à experiência pessoal e estilos de vida. Consoante essa mudança de paradigma, a melhoria da QV passou a ser um dos resultados esperados, tanto das práticas assistenciais quanto das políticas públicas para o setor nos campos da promoção da saúde e da prevenção de doenças. Segundo os autores a Organização Mundial de Saúde conceitua Qualidade de Vida como "a percepção do indivíduo sobre a sua posição na vida, no contexto da cultura e dos sistemas de valores nos quais ele vive, e em relação a seus objetivos, expectativas, padrões e preocupações".

Para Nahas (2006) o conceito de qualidade de vida é diferente de pessoa para pessoa e tende a mudar ao longo da vida de cada um. Porém, existe, consenso em torno da idéia de que são múltiplos os fatores que determinam a qualidade de vida de pessoas ou comunidades. É a 
combinação desses fatores que moldam e diferenciam o cotidiano do ser humano, que resulta numa rede de fenômenos e situações que, abstratamente, pode ser chamada de qualidade de vida. Em geral, associam-se a essa expressão fatores como: estado de saúde, longevidade, satisfação no trabalho, salário, lazer, relações familiares, disposição, prazer e até espiritualidade.

Fernandes (1996) conceitua QVT como uma gestão dinâmica e contigencial de fatores físicos, tecnológicos e sociopsicológicos que afetam a cultura e renovam o clima organizacional, refletindo-se no bem-estar do trabalhador e na produtividade das empresas. A autora explicita que a QVT deve ser considerada uma gestão dinâmica, porque as organizações e as pessoas mudam constantemente, é contigencial, porque depende da realidade de cada empresa, do contexto em que está inserida. Fatores físicos, aspectos sociológicos e psicológicos interferem igualmente na satisfação dos indivíduos em situação de trabalho, sem deixar de considerar os aspectos tecnológicos da organização do próprio trabalho, que, em conjunto, afetam a cultura e interferem no clima organizacional com reflexos na produtividade e na satisfação dos empregados.

Ogata (2008) conceitua Qualidade de Vida no Trabalho como uma série de medidas tomadas pela empresa para estabelecer condições de trabalho que favoreçam o funcionário enquanto ser social capaz de corresponder às próprias demandas em prol do seu bem-estar geral, as demandas da companhia e de relacionar-se com os demais funcionários de forma saudável. No que concerne à empresa, acredita-se que a infra-estrutura da mesma interfira no bem estar do colaborador, porém, esta é secundária diante dos relacionamentos construídos nela. Assim, a gestão da qualidade de vida dentro de uma empresa navega tanto na esfera dos relacionamentos, isto é, na esfera social, quanto em questões de infra-estrutura e saúde.

Para Ferreira e Mendes (2003) a análise do contexto de trabalho é um conceito fundamental para compreensão do impacto da relação entre organização e sociedade. Sendo constituído por três aspectos: a organização do trabalho, as condições de trabalho e as relações socioprofissionais. Compreendendo o que e por que é feito, com o que é feito e com quem é feito, poder-se-ia melhor relacionar o impacto desse novo contexto organizacional sobre as vivências de prazer e sofrimento no trabalho.

A organização do trabalho se refere às regras, normas, foco da produtividade e divisão do trabalho que demonstra a identidade da organização e a forma de lidar com seus processos organizacionais. As condições de trabalho se referem à infra-estrutura oferecida para a realização das atividades, bem como suas práticas de recursos humanos. E por fim, as relações 
socioprofissionais estabelecidas se referem ao aspecto relacional entre pares, chefia e clientes, possibilitando a análise da organização com a sociedade. São essas dimensões, ao serem avaliadas de forma negativa ou positiva pelo trabalhador, as responsáveis pelo desencadeamento das vivências de prazer ou de sofrimento.

Segundo Freitas (2006), o prazer é proveniente da gratificação pulsional, resultante da consonância entre a subjetividade do trabalhador (sonhos, desejos, anseios) e o que é oferecido pelo contexto de trabalho. Vários seriam os indicadores de prazer no trabalho: valorização, reconhecimento, liberdade, realização, gratificação, orgulho no trabalho, capacidade de aprendizagem, sentido no trabalho. Para Ferreira e Mendes (2003), o reconhecimento está relacionado aos sentimentos de valorização, orgulho e identificação com a atividade. Já o sentimento de liberdade está associado à possibilidade de pensar, falar e agir sobre a atividade.

O sofrimento está vinculado a sentimentos como angústia, medo e insegurança, provenientes do conflito entre as necessidades de gratificação e a restrição de satisfazê-las impostas pelas limitações das situações de trabalho. O sofrimento pode ser expresso por meio de sentimentos como ansiedade, insatisfação, solidão, inutilidade, desvalorização e desgaste. O sentimento de desvalorização é definido, segundo Ferreira e Mendes (2003), como o sentimento de insegurança e incompetência do trabalhador perante questões de produtividade e desempenho. Já o desgaste está ligado a sentimentos de cansaço, stress, desânimo, sobrecarga e frustração.

Para não ocorrer uma desestruturação e desequilíbrio mental diante das incertezas, das insatisfações e do sofrimento resultantes das situações de trabalho, as estratégias de mediação tornam-se fundamentais para transformá-los ou negá-los. Segundo Freitas (2006), essas estratégias podem ser defensivas ou de mobilização subjetiva.

As defesas utilizadas pelos trabalhadores, de modo geral, atende ao mesmo tempo uma lógica socio-psíquica e de racionalidade econômica, gerando alianças implícitas, que podem não permitir o confronto das contradições dos modos de produção e conseqüentemente, de um enfrentamento das situações de adversidades. Nesse sentido, a defesa contribui de alguma forma para aceitação do sofrimento mental gerado pela organização capitalista do trabalho e conseqüentemente gera um imobilismo social diante das questões coletivas da categoria profissional. 
A mobilização subjetiva é uma estratégia que possibilita a ressignificação do sofrimento a partir da modificação da realidade que faz sofrer. Tal mobilização se sustenta no coletivo de trabalho, por meio do aspecto público de discussão, socialização do sofrimento, da cooperação e coesão grupais.

Quando essas estratégias falham, o trabalhador pode ser levado ao adoecimento e aparecimento de doenças como depressão e distúrbio osteomuscular relacionado ao trabalho DORT entre outras.

Para Mendes (2004) a Qualidade de Vida no Trabalho vai existir quando os membros da organização forem capazes de gratificar necessidades profissionais por meio das oportunidades oferecidas pelas organizações, que contemple preocupação com o desenvolvimento no trabalho, com a eficácia da organização e com a idéia da participação dos trabalhadores na solução de problemas e tomada de decisões. Inevitavelmente requer a construção de um espaço organizacional que valorize a subjetividade, que considere os trabalhadores sujeitos do seu trabalho e não objetos de produção.

As organizações que querem ter uma atuação mais voltada para as questões de saúde no trabalho devem pesquisar e fazer a gestão da qualidade de vida no trabalho. Mendes (2004) propõe a abordagem teórica da ergonomia da atividade, psicopatologia e psicodinâmica do trabalho e medidas quantitativas e qualitativas como fundamento para essa intervenção.

Segundo a autora, Qualidade de Vida no Trabalho é pesquisada por meio das relações entre organização, condições e relações de trabalho e as vivências de prazer e sofrimento, e a gestão realizada por meio do acompanhamento de grupos ocupacionais, responsáveis pelas discussões, análise e elaboração de estratégias de intervenção.

A organização, condições e relações sociais de trabalho e o prazer e o sofrimento são consideradas antecedentes do clima organizacional e da satisfação, funcionando como um termômetro que indica ou não o bem-estar na organização, para apreensão da qualidade de vida é necessário a introdução de variáveis que dependem das práticas de gestão organizacional voltadas para melhorias das situações adversas ao bem-estar, agregando aspectos de desempenho e da saúde.

Essas variáveis são investigadas por meio de indicadores, conforme propostos abaixo:

Para a organização do trabalho os indicadores são: 
- divisão hierárquica, técnica e social do trabalho, metas, qualidade e quantidade de produção esperada;

- regras formais, missão, normas, dispositivos jurídicos e procedimentos;

- duração da jornada, pausas e turnos;

- $\quad$ ritmos, prazos e tipos de pressão;

- controles como supervisão, fiscalização e disciplina; e

- natureza, conteúdo e características das tarefas.

Os indicadores para as condições de trabalho são:

- ambiente físico como sinalização, espaço, luz, ar, temperatura, som;

- instrumentos, ferramentas, máquinas, documentação;

- equipamentos, materiais arquitetônicos, aparelhagem e mobiliário,

- matéria prima e informacionais;

- suporte organizacional como informações, suprimentos e tecnologias; e

- política de remuneração, desenvolvimento de pessoal e benefícios.

Para as relações sociais de trabalho os indicadores considerados são:

- interações hierárquicas;

- interações coletivas intra e inter-grupos; e

- interações externas com clientes, usuários, consumidores, representantes institucionais e fornecedores.

O prazer é avaliado por dois indicadores:

- realização, que é o sentimento de gratificação, orgulho e identificação com o trabalho profissional; e 
- liberdade, que é o sentimento de estar livre para pensar, organizar e falar sobre o trabalho.

E o sofrimento é avaliado pelos seguintes indicadores:

- desgaste, sentimento de desânimo, cansaço, ansiedade, frustração, tensão emocional, sobrecarga e estresse no trabalho; e

- desvalorização, sentimento de incompetência diante das pressões para atender as exigências de desempenho e produtividade.

Mendes (2004) propõe que com base na pesquisa desses indicadores sejam elaboradas as estratégias de gestão da qualidade de vida, que devem ser voltadas para a (re) estruturação da organização, condições e relações sociais, construção de um coletivo de trabalho e para a promoção e/ou desenvolvimento de um certo grau de autonomia e competência, com vistas a participação efetiva dos trabalhadores na gestão do próprio trabalho.

\subsection{A Psicodinâmica do Trabalho}

O maior representante da psicodinâmica do trabalho é o psiquiatra francês Christopher Dejours. No início da década de 80 ele iniciou estudos nessa área, centrado em pesquisas sobre o sofrimento psíquico, buscando sua origem e as transformações resultantes do confronto entre o psíquico do trabalhador e a organização do trabalho.

As pesquisas que marcam a primeira fase do modelo desenvolvido por Dejours, surgiram em função da preocupação que sindicatos e instituições de saúde, no final da década de 60, tinham com as patologias mentais provenientes do trabalho, basicamente com os trabalhadores semiqualificados (construção civil, serviço público, telefonistas).

Devido as pesquisas realizadas nesta fase, a atenção se voltou para a organização do trabalho baseada no padrão taylorista. Assim, a organização do trabalho, a qual apresentava como característica a rigidez, o trabalho racionalizado e repetitivo e muita pressão para o 
exercício das atividades, era segundo Dejours, a principal fonte de estabilização da saúde mental dos trabalhadores.

Nesta fase, além de considerar a organização do trabalho como a desestabilizadora da saúde mental dos trabalhadores, o sofrimento foi caracterizado como medo, ansiedade e frustração. Estudaram-se, também, os tipos de defesa individuais e coletivas. O prazer não foi analisado nesse período.

Para exemplificar a segunda fase, pode-se citar o estudo realizado por Mendes e Abrahão (1996), com engenheiros de uma empresa de telecomunicações. Observou-se que o prazer se associa ao reconhecimento e à valorização do trabalhador pela organização, pelos resultados produtivos e pelo processo descentralizado das decisões e flexibilidade hierárquica. Já o sofrimento associa-se à divisão e padronização de tarefas, à subutilização da criatividade e potencial técnico, à rigidez hierárquica, à falta de participação nas decisões, as ingerências políticas, à pouca perspectiva de crescimento profissional entre outras.

Nos estudos mais recentes com relação a psicodinâmica do trabalho, o enfoque tem sido mais amplo, pois o trabalho é percebido como lócus de construção da identidade do trabalhador. Estudam-se, também, a dinâmica do reconhecimento e as estratégias de mediação do prazer-sofrimento, as novas formas de organização do trabalho e seu impacto sobre as vivências de prazer e sofrimento. E também se analisa o saudável no ambiente de trabalho, a dinâmica que envolve as inter-relações entre prazer, sofrimento e saúde.

O referencial desta fase são as mudanças socioeconômicas que começaram a acontecer a partir da década de 70 do século XX. Neste contexto, há um processo de reorganização da produção, saindo de uma lógica taylorista de base rígida, para uma lógica de flexibilidade no trabalho, ou seja, uma nova organização do processo produtivo.

O trabalho é analisado numa perspectiva dialética, pois é fonte de prazer e de sofrimento. Quando há sofrimento, é possível transformá-lo em prazer por meio da mobilização subjetiva ou pelas estratégias de defesas.

Dejours considera que as estratégias de defesas são ações coletivas. Que em geral, acontecem quando o grupo compartilha coletivamente o sofrimento e busca formas de resolução das situações causadoras do sofrimento. Ao utilizar defesas, o trabalhador pode 
neutralizar o sofrimento e, por conseguinte, passar por um processo de alienação e cristalização, o que pode dificultar mudança nas situações de trabalho.

Várias pesquisas foram realizadas no campo das estratégias defensivas. Segundo Freitas (2006) podemos citar as realizadas por Mendes (1994, 1996), Linhares (1994) e Mendes e Linhares (1996). Nessas pesquisas, conclui-se que comportamentos defensivos são encontrados de maneira diferenciada em cada profissão. Encontraram-se os seguintes indicadores de comportamentos defensivos nos estudos realizados com funcionários públicos:

a) racionalização e/ ou passividade e aceitação diante do elemento que faz sofrer e

b) individualismo e trabalho solitário diante de situações como falta de cooperação, de confiança, de compartilhamento de regras no grupo.

$\mathrm{Na}$ trajetória teórica da psicodinâmica do trabalho, é possível observar que o sofrimento, quando não é enfrentado por meio das estratégias defensivas ou pela mobilização subjetiva, pode-se tornar um caminho para o adoecimento.

Segundo Freitas (2006), o sofrimento é proveniente das sensações dolorosas diante do conflito entre desejo e realidade. Funciona, sobretudo, como um sintoma, pois alerta o indivíduo de que algo não está bem, que geralmente é expresso pela insatisfação e a ansiedade, sendo que a insatisfação manifesta-se por meio de vivências depressivas, que expressam uma sensação de adoecimento intelectual, de paralisia da imaginação e marcam o triunfo do condicionamento ao comportamento produtivo.

Leme (2000), ao analisar o significado do programa de demissões voluntárias (PDV) junto aos bancários do Banco do Brasil, identifica o predomínio de sofrimento. De acordo com Leme, o sofrimento se manifesta por meio de conflitos pessoais e do sentimento de frustração em decorrência da forma como o programa foi conduzido.

Ainda, sobre o estudo com bancários, Freitas (2006) mostra como indicadores de sofrimento a desvalorização no trabalho, a sobrecarga, a ameaça de desemprego e o controle por parte das chefias. Ele identifica que o sofrimento é suportado devido ao medo do desemprego. Assim, os trabalhadores, na busca de manter o emprego, numa sociedade que prima inexoravelmente pelo consumo, passam a suportar todo tipo de constrangimento para que o emprego seja garantido. 
Segundo Freitas (2006), Dejours ao estudar a situação dos desempregados na França, refletiu sobre a dinâmica do reconhecimento. Para o autor, o desemprego faz com que as pessoas sofram por não serem úteis à sociedade, pois não podem contribuir socialmente e, portanto, não são reconhecidas por meio do trabalho.

Segundo Dejours (1999), o não reconhecimento do trabalho pelo outro pode gerar crise de identidade e doença. Em contrapartida, quando há reconhecimento, o sujeito tem um sentimento de pertencer a um grupo. Isto fortalece a identidade e propicia uma valorização da auto-estima do trabalhador.

Em pesquisa qualitativa, Rocha (2003) investigou bancários acometidos de DORT. Esta pesquisa teve como objetivo central estudar o contexto do trabalho (organização do trabalho, condições de trabalho e relações socioprofissionais) e sua relação com as vivências de prazer-sofrimento e estratégias de mediação do sofrimento.

A pesquisa de Rocha representa um no estágio da psicodinâmica do trabalho estudado na Universidade de Brasília, tendo em vista o diálogo com a ergonomia da atividade.

Abaixo, serão apresentados os principais conceitos da ergonomia da atividade com vistas à construção do diálogo entre as duas disciplinas.

\subsection{A Ergonomia da Atividade}

Atualmente esta disciplina é estudada por duas correntes, a americana e a européia. A corrente de filiação americana está voltada para o processo de concepção de dispositivos, tais como máquinas, ferramentas etc., visando à melhoria dos equipamentos de trabalho, desenvolvendo os seus estudos em laboratórios, ou seja, fora da realidade do trabalho. A européia está relacionada à tarefa do operador, sobretudo ao modo como este executa sua atividade. Tem como foco de atuação a situação real de trabalho, na qual é possível identificar os processos que geram problemas ao trabalhador.

Segundo Ferreira (2003), a abordagem ergonômica utilizada na presente pesquisa, tem suas raízes históricas no processo de intervenção nos ambientes de trabalho e nas reflexões teóricas desenvolvidas em países de língua francesa, por diferentes estudiosos e profissionais, 
a partir dos anos 50 do século XX. O contato com reais situações de trabalho é fundamental para análise ergonômica, o que se busca é a adaptação do trabalho ao homem e não o contrário.

A análise ergonômica da atividade compreende o processo de estudo das estratégias de regulação e dos modos operatórios, utilizados pelos trabalhadores para gerenciar a distância que há entre o homem e a tarefa. A atividade é o elemento principal que estrutura a análise das situações de trabalho, possibilitando o estudo profundo da realidade de trabalho evidenciando a variabilidade dos modos de trabalho, que tem como pressuposto básico as diferenças que há nos sujeitos, as quais se expressam na experiência de cada um. Essas diferenças impactam na atividade do trabalhador, na forma como realiza o trabalho.

Para a ergonomia francofônica, o trabalho é a articulação entre a atividade, as condições para sua realização e o resultado da atividade. Esses três elementos são interdependentes.

Em estudo realizado por Ferreira e Freire (2001) sobre a inter-relação entre carga de trabalho e rotatividade sistemática, em um ambiente de atendimento ao público de um posto de distribuição de combustível, demonstrou-se que em relação ao trabalho prescrito há uma certa tendência, na empresa estudada, para uma concepção tecnocêntrica, na qual o homem é percebido como uma variável de ajuste. Em relação ao trabalho real, ficou evidenciado múltiplas exigências (cognitivas, físicas e psíquicas), as quais expressam o custo humano no trabalho. Porém, observou-se uma discrepância entre o trabalho prescrito e o trabalho real, o que produz alta rotatividade de pessoal na instituição pesquisada.

\subsection{O diálogo entre ergonomia da atividade e psicodinâmica do trabalho}

O enfoque adotado por Ferreira e Mendes (2003), para investigar a influência entre o contexto de trabalho e a Psicodinâmica, fundamenta-se em dois pressupostos complementares. O primeiro sucedeu principalmente da ergonomia da atividade, refere-se à atividade do sujeito propriamente dita, onde, a atividade caracteriza-se como um processo permanente de regulação e mediação que visa o ajuste do trabalhador às tarefas prescritas, ou 
às múltiplas determinações do contexto de trabalho (físicas, instrumentais, materiais, organizacionais, situacionais e sociais).

O segundo está ligado à avaliação que o trabalhador faz de seu estado interno, resultando em vivências de prazer-sofrimento, que pode ser compartilhada coletivamente e é influenciada pela atividade de trabalho.

Conclui-se desses pressupostos, que toda atividade laboral introduz um custo humano que se expressa sob a forma de carga de trabalho, e as vivências de prazer e sofrimento têm como um dos resultantes o conflito do sujeito com essa carga (trabalho real e trabalho prescrito) que, por conseguinte, impacta nas vivências subjetivas e no sentido e significado atribuído ao contexto de trabalho. Para isso, o sujeito utiliza três estratégias de mediação que visam manter a integridade física, psíquica e social.

Ferreira e Mendes (2003) indicam que as principais estratégias de mediação individual e coletiva utilizadas pelos trabalhadores são: as estratégias operatórias (ligadas à ergonomia da atividade), as estratégias de mobilização coletiva e as estratégias defensivas (ligadas à psicodinâmica do trabalho).

Como podemos observar Dejours segue a mesma linha de raciocínio:

\begin{abstract}
Já que, na sua maioria, aqueles que trabalham conseguem evitar deslizar na doença mental (descompensação psicopatológica), podemos admitir que, aquém da doença mental, existem estados de sofrimento compatíveis com o prosseguimento do trabalho e uma inserção conveniente na sociedade. Se os referidos sofrimentos não levam à aparição de doenças mentais, é porque contra elas os homens e as mulheres que trabalham constroem "defesas". Estratégias individuais e estratégias coletivas permitem controlar em muitos casos os efeitos deletérios do sofrimento sobre a saúde mental. Assim a normalidade se apresenta como um compromisso ganho, após lutas ferrenhas, graças ao ajuste das defesas para enfrentar o sofrimento no trabalho (DEJOURS, 2000 apud LIMONGI-FRANÇA 2004).
\end{abstract}

As duas disciplinas, também, se aproximam pelas suas origens históricas semelhantes, ambas surgiram no século XX, na Europa, e com vínculos entre cientistas e o movimento sindical dos trabalhadores na busca comum de melhorias das condições de trabalho. E, além disso, os fundamentos teóricos da Ergonomia da Atividade se sustentam na psicologia e fisiologia, e a Psicodinâmica do Trabalho tem suas raízes epistemológicas no existencialismo, na psicanálise e na psicossociologia. 


\section{Metodologia}

A pesquisa pretende identificar e diagnosticar os riscos de adoecimento no trabalho, para o alcance deste objetivo a seguir serão apresentados o tipo de pesquisa a ser desenvolvido, a amostra a ser pesquisada, o instrumento a ser aplicado, os procedimentos a serem adotados e a forma de análise dos dados coletados.

\subsection{Tipo de Pesquisa}

No que se refere aos fins, a pesquisa realizada será do tipo qualitativa e descritiva, segundo Vergara (2000, p. 47) uma pesquisa do tipo descritiva "expõe características de determinada população ou de determinado fenômeno".

No que se refere aos meios, a pesquisa realizada será a de campo, "que é uma investigação empírica realizada no local onde ocorre ou ocorreu um fenômeno ou que dispõe de elementos para explicá-lo" Vergara (2000, p. 47). Permitindo a realização de uma fotografia dos fatos a serem estudados, pois fornece índices precisos e objetivos sobre o assunto.

\subsection{Participantes}

Para a realização da pesquisa foram escolhidos, por conveniência, por serem de segmentos diferenciados e os mais afetados pelo Programa de Transformação realizado em 2003, os profissionais das Áreas Compartilhadas das Entidades Nacionais do Sistema Indústria, atualmente composta de 200 profissionais com níveis de escolaridade e cargos hierárquicos diferenciados, com o objetivo identificar a percepção de profissionais de todos os níveis hierárquicos do Sistema Indústria.

A pesquisa foi enviada para 170 profissionais, destes apenas 76 responderam a pesquisa. 
O resultado da pesquisa demonstrou que a empresa caracteriza-se por profissionais do sexo feminino (57,9\%), com pós-graduação $(59,2 \%)$ e casado $(57,9 \%)$, com média de 37 anos de idade, até 5 anos de tempo de serviço na empresa e até 5 anos de tempo de serviço no cargo que desempenha atualmente.

Esse perfil indica uma amostra representativa de profissionais qualificados, jovens e com média experiência na organização e no cargo.

As descrições detalhadas dos dados estão apresentadas nas tabelas abaixo:

Tabela 1 - Frequiência de respostas para o campo "gênero".

\begin{tabular}{||l||r|r|}
\hline \multicolumn{1}{|c|}{ Gênero } & Freqüência & Porcentagem \\
\hline \hline Masculino & 32 & 42,1 \\
\hline \hline Feminino & 44 & 57,9 \\
\hline \hline Total & 76 & 100,0 \\
\hline
\end{tabular}

Tabela 2 - Freqüência de respostas para o campo "escolaridade".

\begin{tabular}{|l|r|r|}
\hline \multicolumn{1}{|c|}{ Escolaridade } & Freqüência & Porcentagem \\
\hline \hline Até segundo grau & 1 & 1,3 \\
\hline \hline Superior Incompleto & 7 & 9,2 \\
\hline \hline Superior & 23 & 30,3 \\
\hline \hline Pós-graduação & 45 & 59,2 \\
\hline Total & 76 & 100,0 \\
\hline \hline
\end{tabular}


Tabela 3 - Freqüência de respostas para o campo "estado civil”".

\begin{tabular}{||l|r|r|}
\hline \multicolumn{1}{|c|}{ Estado Civil } & Freqüência & Porcentagem \\
\hline \hline Casado & 44 & 57,9 \\
\hline \hline Solteiro & 24 & 31,6 \\
\hline \hline Separado/divorciado & 5 & 6,6 \\
\hline \hline Sub-total & 73 & 96,1 \\
\hline \hline Perdidos & 3 & 3,9 \\
\hline \hline Total & 76 & 100,0 \\
\hline
\end{tabular}

Tabela 4 - Freqüência de respostas para o campo "faixa etária".

\begin{tabular}{|l|r|r|}
\hline \multicolumn{1}{|c|}{ Faixas Etárias } & Freqüência & Porcentagem \\
\hline \hline Até 31 anos & 23 & 30,3 \\
\hline Entre 32 e 40 anos & 26 & 34,2 \\
\hline \hline Mais de 40 anos & 24 & 31,6 \\
\hline Sub-total & 73 & 96,1 \\
\hline \hline Perdidos & 3 & 3,9 \\
\hline \hline Total & 76 & 100,0 \\
\hline \hline
\end{tabular}

Tabela 5 - Freqüência de respostas para o campo "tempo de serviço na Instituição".

\begin{tabular}{|l|r|r|}
\hline $\begin{array}{c}\text { Tempo de serviço na } \\
\text { Instituição }\end{array}$ & Freqüência & Porcentagem \\
\hline Até 5 anos & 30 & 39,5 \\
\hline De 6 a 10 anos & 16 & 21,1 \\
\hline \hline De 11 a 15 anos & 6 & 7,9 \\
\hline Acima de 15 anos & 24 & 31,6 \\
\hline Total & 76 & 100,0 \\
\hline
\end{tabular}


Tabela 6 - Freqüência de respostas para o campo "tempo de serviço no cargo".

\begin{tabular}{|c|r|r|}
\hline $\begin{array}{c}\text { Tempo de Serviço no } \\
\text { cargo }\end{array}$ & Freqüência & Porcentagem \\
\hline \hline Até 5 anos & 48 & 63,2 \\
\hline \hline De 6 a 10 anos & 15 & 19,7 \\
\hline \hline De 11 a 15 anos & 4 & 5,3 \\
\hline \hline Acima de 15 anos & 9 & 11,8 \\
\hline \hline Total & 76 & 100,0 \\
\hline
\end{tabular}

Tabela 7 - Freqüiência de respostas para o campo "cargo atual".

\begin{tabular}{||l||r|r|}
\hline \multicolumn{1}{|c|}{ Cargo atual } & Freqüência & \multicolumn{1}{c|}{ Porcentagem } \\
\hline \hline Gerencial & 10 & 13,16 \\
\hline \hline Técnico & 43 & 56,58 \\
\hline \hline Administrativo & 19 & 25,0 \\
\hline \hline Total & 72 & 94,74 \\
\hline \hline Perdidos & 4 & 5,26 \\
\hline \hline Total & 76 & 100,0 \\
\hline
\end{tabular}

\subsection{Instrumento}

O instrumento de pesquisa a ser utilizado será o de coleta de dados, por meio de questionário enviado por e-mail para os profissionais que tenham acesso ao correio eletrônico. O questionário será composto pelo Inventário de Trabalho e Riscos de Adoecimento (ITRA) e 2 (duas) perguntas abertas:

- O que é, para você, Qualidade de Vida no Trabalho?

- Quais ações de Qualidade de Vida no Trabalho você considera prioritárias? 
O Inventário de Trabalho e Riscos de Adoecimento (ITRA) é um instrumento de pesquisa validado por Mendes e Ferreira (2003), que tem por objetivo traçar um perfil dos antecedentes, medidores e efeitos do trabalho no processo de adoecimento. Com a aplicação do ITRA pretende-se investigar o trabalho e os riscos de adoecimento por ele provocado em termos de representação do contexto de trabalho, exigências (físicas, cognitivas e afetivas) vivências e danos. Objetiva mensurar distintas e interdependentes modalidades de representações dos respondentes, referentes ao mundo do trabalho. Essas representações são compostas por 4 categorias:

- descrição do contexto de trabalho: referente as representações dos trabalhadores sobre as condições do trabalho, a organização e as relações socioprofissionais. É avaliada pela Escala de Avaliação do Contexto de Trabalho (EACT);

- descrição das exigências: são as representações referentes ao custo físico, cognitivo e afetivo do trabalho. É avaliada pela Escala de Custo Humano no Trabalho (ECHT);

- descrição do sentido do trabalho: é representada pelas vivências de prazer e de sofrimento no trabalho. É avaliada pela Escala de Indicadores de Prazer $e$ Sofrimento no Trabalho (EIPST);

- descrição dos efeitos do trabalho para a saúde: são as representações quanto às conseqüências do trabalho relacionadas aos danos físicos e psicossociais. É avaliada pela Escala de Avaliação dos Danos Relacionados ao Trabalho (EADRT).

Segundo Mendes (2007), o ITRA capta a representação do real na dimensão mais visível e compartilhada pela maioria dos trabalhadores de um determinado grupo.

\subsection{Histórico do Programa Qualidade de Vida do Sistema Indústria}

O SESI/DN, no âmbito de sua responsabilidade social, implantou, em abril de 2002, o 
Programa SESI Qualidade de Vida do Funcionário, que visava o bem estar dos funcionários, o aumento da produtividade, o aprimoramento do ambiente de trabalho e o atendimento da legislação vigente de saúde e segurança do trabalhador.

O programa era coordenado pelo SESI/DN, a qual competia planejar e implementar ações que garantissem a valorização do capital humano, não apenas do SESI/DN, mas de todas as Entidades do Sistema Indústria: Confederação Nacional da Indústria - CNI, Serviço Social da Indústria - Departamento Nacional - SESI/DN, Serviço Nacional de Aprendizagem Industrial - Departamento Nacional - SENAI/DN e Instituto Euvaldo Lodi/Núcleo Central IEL/NC. Para isso, cada Entidade indicou um representante da sua área de recursos humanos para compor a equipe do Programa Qualidade de Vida.

O escopo do Programa era potencializar as antigas e novas tecnologias de Qualidade e Produtividade e garantir as quatro dimensões do ser humano:

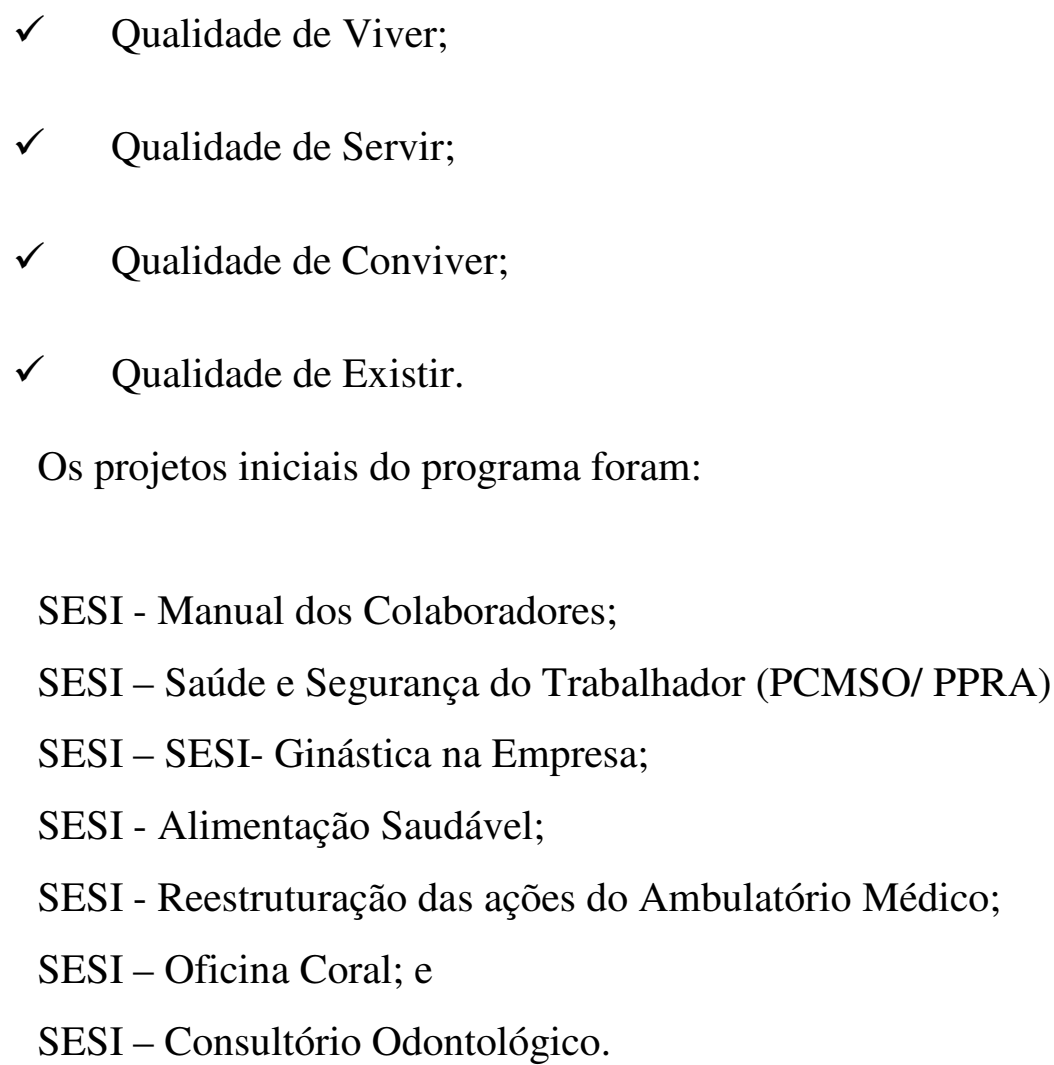

O objetivo do programa era a promoção do bem-estar físico e mental dos funcionários, através da melhoria do ambiente de trabalho, da redução do stress, redução do absenteísmo, aumento da auto-estima, aumento da produtividade e da motivação. 


\section{METAS DO PROGRAMA:}

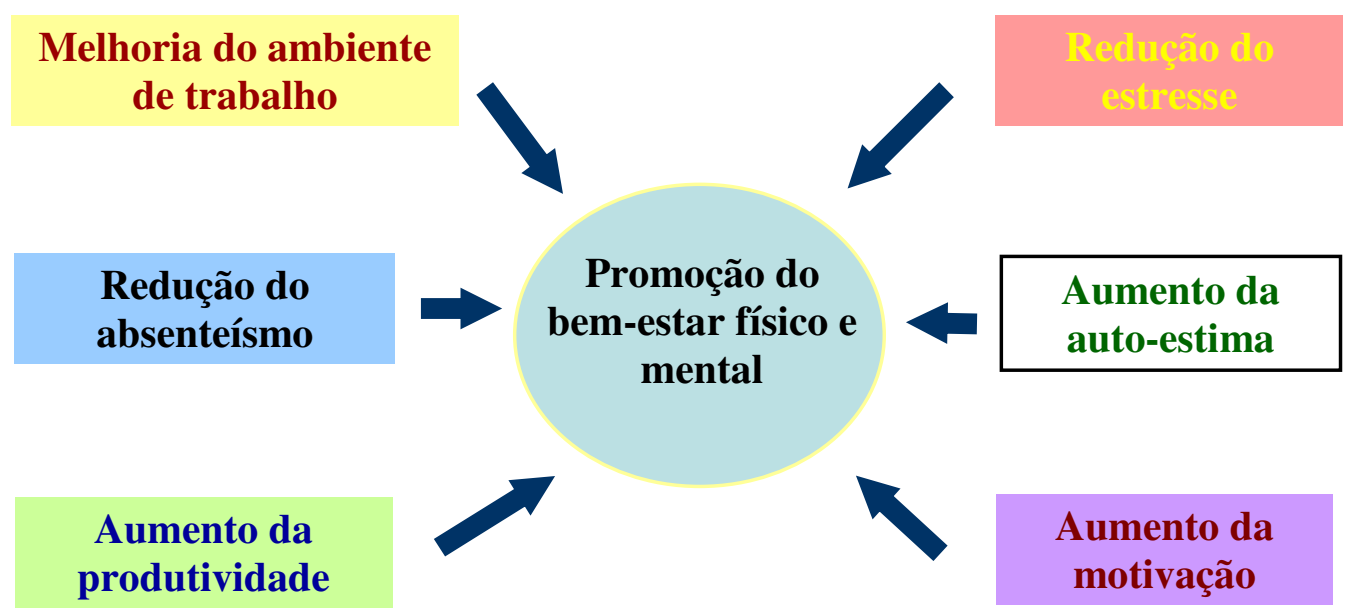

Figura 1 - Metas do Programa Qualidade de Vida (2002).

Fonte: Sistema Indústria (2002)

Em 2003, o Sistema Indústria passou por uma mudança na sua estrutura organizacional, na qual foram criadas as chamadas áreas de serviços compartilhados e as unidades corporativas, visando obter os "chamados" ganhos de produção e consequientemente melhorar os resultados financeiros. A mudança foi chamada de Programa de Transformação.

As áreas compartilhadas e unidades corporativas são consideradas como áreas/unidades que suportam as atividades de negócio, as chamadas áreas meio, nos assuntos referentes à administração, recursos humanos, financeiros, tecnologia da informação, arrecadação e convênios.

Com a mudança na estrutura organizacional, a Área Compartilhada de Recursos Humanos concentrou todas as políticas e práticas de gestão de pessoas e do Programa Qualidade de Vida das quatro Entidades do Sistema Indústria.

No ano de 2004 até meados de 2005 o Programa passou por uma fase de adormecimento, devido ao Programa de Transformação, pois todas as áreas compartilhadas tinham que montar suas equipes e serem estruturadas e adequadas ao novo modelo de gestão, o que gerou uma instabilidade muito grande para os profissionais, pois mesmo fazendo parte de um mesmo Sistema, cada Entidade tinha sua cultura e seus valores.

As únicas ações realizadas neste período eram as campanhas de prevenção: 
vacinação contra gripe, DST/AIDS e hipertensão, o Programa de Ginástica na Empresa, os programas de saúde e segurança do trabalhador - Programa de Prevenção de Riscos Ambientais - PPRA, Programa de Controle Médico de Saúde Ocupacional - PCMSO e a Oficina Coral, que acabou sendo desativada pelo baixo número de participantes.

Em 2005, o Programa de Controle Médico de Saúde Ocupacional - PCMSO foi realizado em conjunto com a seguradora de saúde contratada pelo Sistema Indústria. A seguradora de saúde possui um programa de Qualidade de Vida que visa reduzir a incidência de Infartos, Derrames e Doenças Crônicas, através do controle e redução dos fatores de risco:

- Sedentarismo

- Hipertensão Arterial

- Obesidade

- Tabagismo

- Colesterol Elevado

- Diabetes Mellitus

Quatrocentos e setenta (470) funcionários participaram do programa de Qualidade de Vida da seguradora, conforme figura 2.

\begin{tabular}{|c|c|c|}
\hline \multicolumn{3}{|l|}{ TOTAL NA EMPRESA POR ÁREA } \\
\hline EMPRESA: & \multirow{3}{*}{\multicolumn{2}{|c|}{$\begin{array}{l}\text { SISTEMA INDUSTRIA } \\
\mathbf{0 1 / 6 / 2 0 0 5} \\
\mathbf{0 1 / 1 0 / 2 0 0 5}\end{array}$}} \\
\hline DATA INICIAL: & & \\
\hline DATA FINAL: & & \\
\hline Área & Total Área & Idade Média \\
\hline ÁREA COMPARTILHADA & 113 & 37 \\
\hline $\mathrm{CNI}$ & 93 & 43 \\
\hline IEL & 23 & 34 \\
\hline SENAI & 87 & 42 \\
\hline SESI & 111 & 42 \\
\hline UNIDADE CORPORATIVA & 43 & 39 \\
\hline \multicolumn{3}{|l|}{ Iotalizaçốes: } \\
\hline Total de Funcionários & 470.0 & \\
\hline
\end{tabular}

Figura 2: Número de participantes PAQV Fonte: Sistema Indústria (2005) 
O resultado do PCMSO em conjunto com o Programa de Qualidade de Vida da seguradora de saúde, acendeu a luz vermelha para o Programa Qualidade de Vida do Sistema Indústria, pois o resultado mostrou que os funcionários do Sistema Indústria corriam o risco de adoecerem quase a metade da empresa era sedentária (48\%), conforme demonstrado no gráfico 1:

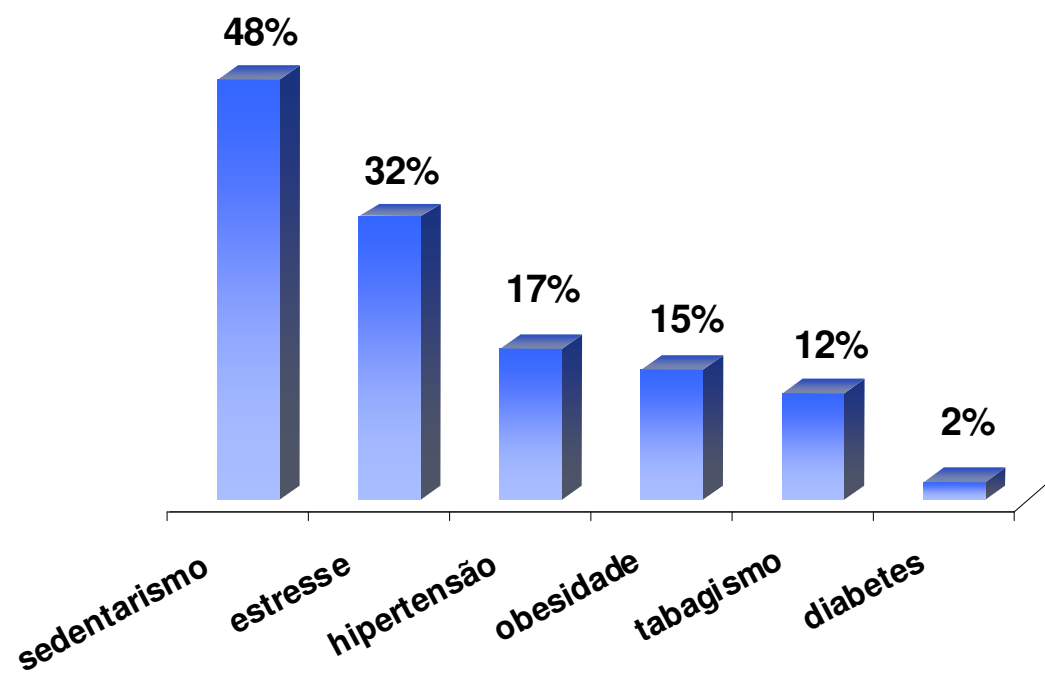

Gráfico 1: Resultado PCMSO

Fonte: Sistema Indústria (2005)

Em 2005, também foi realizada uma pesquisa interna com o objetivo de reconhecer as necessidades e expectativas dos colaboradores, com foco nas ações que já eram realizadas e na integração dos colaboradores. O foco em saúde era unicamente no cumprimento da legislação vigente: PPRA e PCMSO.

O ano de 2006 foi de reestruturação para o Programa Qualidade de Vida, passando a ter como foco principal a prevenção e promoção da saúde. Foi o ano de lançamento do Programa Lazer Ativo, que é um programa abrangente de promoção de um estilo de vida ativo, considerado como elemento fundamental para a saúde e a qualidade de vida do trabalhador e seus familiares. Baseia-se na informação, estímulo e criação de oportunidades para que os sujeitos modifiquem condutas de risco à saúde, passando a adotar estilos de vida mais ativos e saudáveis.

No Lazer Ativo, a atividade física é o "carro-chefe" das intervenções, mas outras condutas de saúde devem ser focalizadas. 
Esquematicamente um programa de promoção de estilos de vida ativos e saudáveis, como o Lazer Ativo, representa o conjunto de intervenções e ações de natureza educacional, ambiental e organizacional, implementadas a fim de: promover a redução na prevalência de exposição a fatores de risco e na incidência de agravos; e, motivar e apoiar a adoção de estilos de vida mais saudáveis.

Do ponto de vista dos benefícios ao trabalhador, o que se pretende é garantir que através de diferentes produtos e atividades se possa influenciar positivamente os estilos de vida dos trabalhadores e de seus familiares. Alguns dos objetivos do Lazer Ativo são:

- Aumentar o nível de atividades físicas

- Aumentar o nível de conhecimento sobre estilos de vida saudáveis

- Aumentar o nível de interesse dos trabalhadores em relação à própria saúde e aos fatores que a afetam

- Eliminar barreiras para adoção de estilos de vida mais ativos e saudáveis

- Promover a adoção de outras condutas concorrentes com um estilo de vida saudável

Em 2007, o Programa Qualidade de Vida foi reestruturado, seguindo algumas das diretrizes do Lazer Ativo e passou a ter três diretrizes básicas:

\section{- Saúde preventiva}

Cujo objetivo é promover a análise do ambiente de trabalho e da saúde dos funcionários, com base nos meios físicos, ambientais e psicossociais, combatendo o estresse e outras doenças, principalmente as que são decorrentes do trabalho.

Ações relacionadas: Nutricionista, Avaliador Físico, Fisioterapeuta, Massagem Expressa, Programa de Correção Postural, entre outras.

\section{- Socializacãão}

Cujo objetivo é proporcionar ações que promovam a integração entre os funcionários do Sistema Indústria melhorando as relações interpessoais e possibilitando a troca de informação/conhecimento.

Ações relacionadas: Torneios Esportivos, Um dia no trabalho dos pais, Inclusão Digital, Planejamento Financeiro Familiar, entre outras.

\section{- Parcerias}


Cujo objetivo é estabelecer convênios com organizações que ofereçam serviços diferenciados de forma a promover melhoria da qualidade de vida dos funcionários e seus dependentes.

Exemplos: Universidades, cursos de idiomas e clínicas de RX odontológicos.

\subsection{Análise dos Dados}

Os dados obtidos foram submetidos à análise estatística através do software SPSS (Statistical Package for Social Science). Foram realizadas 3 (três) tipos de análise:

- Descritiva: média e desvio padrão dos fatores e dos itens

- Freqüência: distribuição percentual de respostas nos níveis de análise que são críticos

- Análise de Variância (ANOVA) que visa identificar as diferenças intragrupo nos dados demográficos coletados.

Os resultados de desvio padrão para todos os fatores indicam baixa dispersão de respostas.

As perguntas abertas não serão analisadas nesse trabalho. 


\section{Resultados}

A aplicação do instrumento de pesquisa - ITRA foi feita no período de 7 a 22 de fevereiro de 2008, para 170 profissionais das áreas compartilhadas que tinham acesso ao correio eletrônico. O e-mail com o link para responder a pesquisa foi enviado pela gerente executiva da Área Compartilhada de Recursos Humanos - APÊNDICE A. Destes 170 profissionais, 76 responderam a pesquisa.

\subsection{Resultado da Escala de Avaliação do Contexto de Trabalho (EACT)}

A Escala de Avaliação do Contexto de Trabalho - EACT é composta por três fatores: organização do trabalho, condições de trabalho e relações socioprofissionais.

A escala é de 5 pontos, onde:

\begin{tabular}{|c|c|c|c|c|}
\hline 1 & 2 & 3 & 4 & 5 \\
\hline Nunca & Raramente & Às vezes & Frequentemente & Sempre \\
\hline
\end{tabular}

É construída com itens negativos, devendo ser analisado por fator e com base em três níveis diferentes, considerando um desvio padrão em relação ao ponto médio, cujos resultados são classificados conforme abaixo:

- Acima de 3,7 = avaliação mais negativa - grave

- Entre 2,3 e 3,69 = avaliação mais moderada - crítico

- Abaixo de 2,29 = avaliação mais positiva - satisfatório

No gráfico 2, estão destacadas as médias de cada fator que compõem o contexto de trabalho. Os resultados de desvio padrão para todos os fatores indicam baixa dispersão de respostas. 


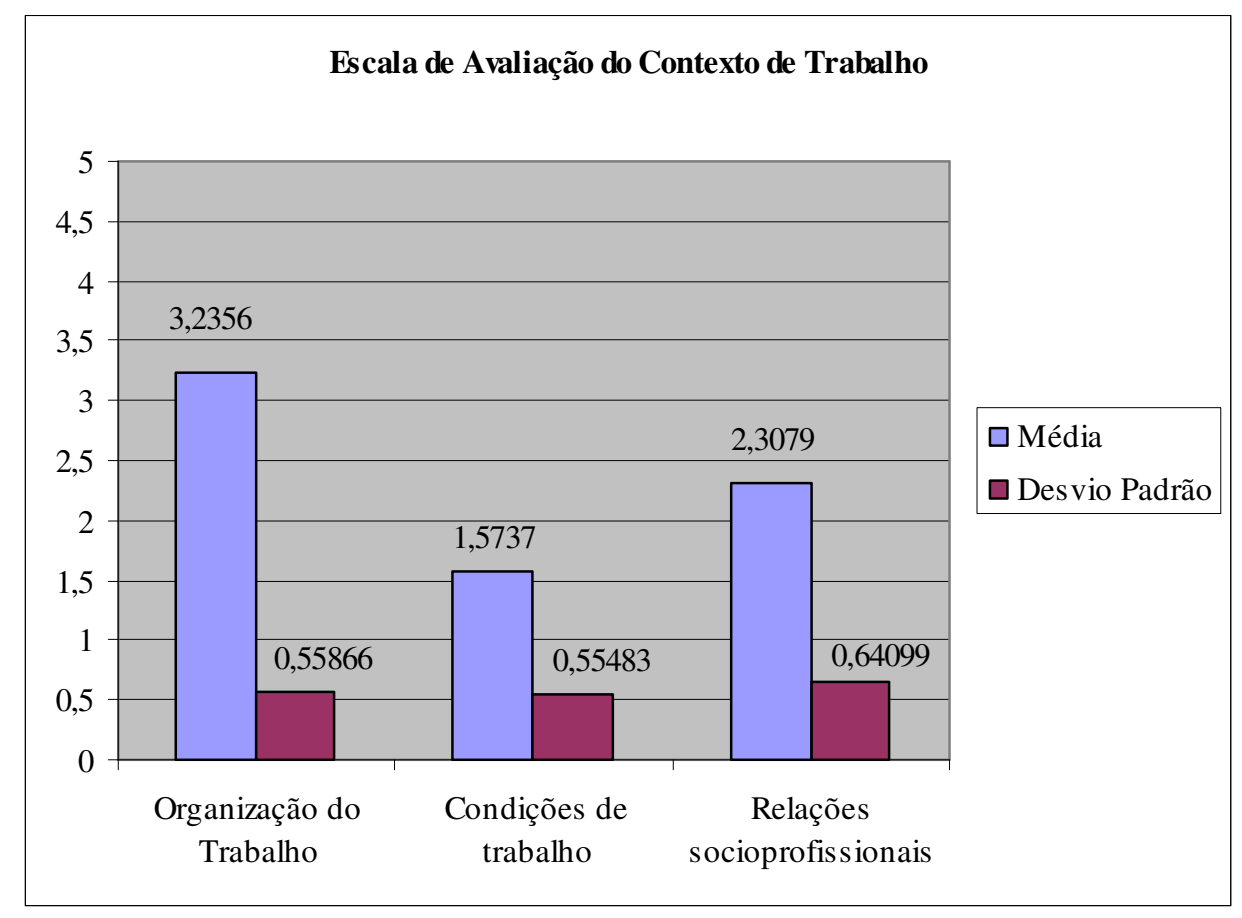

Gráfico 2 - Escala de Avaliação do Contexto de Trabalho

Nos próximos itens serão apresentados os resultados obtidos de cada fator da Avaliação do Contexto de Trabalho.

\subsubsection{Organização do trabalho}

Os resultados para organização do trabalho - gráfico 3 - revelam que os profissionais a percebem como crítica $(78 \%)$, grave $(17 \%)$ e somente $(5 \%)$ a consideram satisfatória.

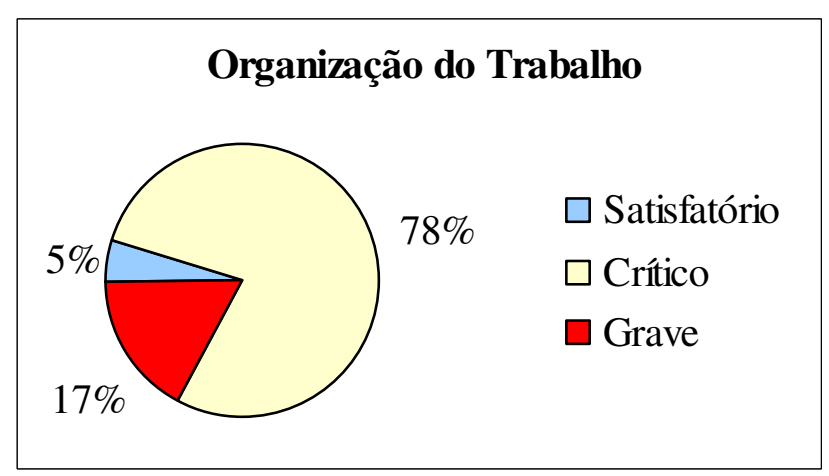

Gráfico 3 - Organização do Trabalho 
Na tabela 8, destacam-se os dois itens do fator organização do trabalho que obtiveram as médias mais positivas, com o objetivo de indicar quais os elementos são os mais satisfatórios.

Tabela 8 - Organização do Trabalho: Itens mais satisfatórios

\begin{tabular}{|l|r|r|}
\hline \multicolumn{1}{|c|}{ Itens mais satisfatórios } & Média & Desvio Padrão \\
\hline As tarefas executadas sofrem descontinuidade & 2,61 & 0,850 \\
\hline Os resultados esperados estão fora da realidade & 2,41 & 0,851 \\
\hline
\end{tabular}

Na tabela 9, destacam-se os dois itens do fator organização do trabalho que obtiveram as médias mais negativas, com o objetivo de verificar quais os elementos são os mais graves.

Tabela 9 - Organização do Trabalho: Itens mais graves

\begin{tabular}{|l|r|r|}
\hline \multicolumn{1}{|c|}{ Itens mais graves } & Média & Desvio Padrão \\
\hline As tarefas são cumpridas com pressão de prazos & 3,80 & 0,938 \\
\hline Existe fiscalização do desempenho & 3,72 & 0,961 \\
\hline
\end{tabular}

Vale ressaltar que o item "Existe forte cobrança por resultado" obteve média de 3,71, ficando muito próximo do item sobre fiscalização do desempenho.

\subsubsection{Condições de Trabalho}

Os resultados para condições de trabalho - gráfico 4 - demonstram que os profissionais a consideram satisfatória ( $84 \%)$, crítica (16\%) e ninguém a considera grave.

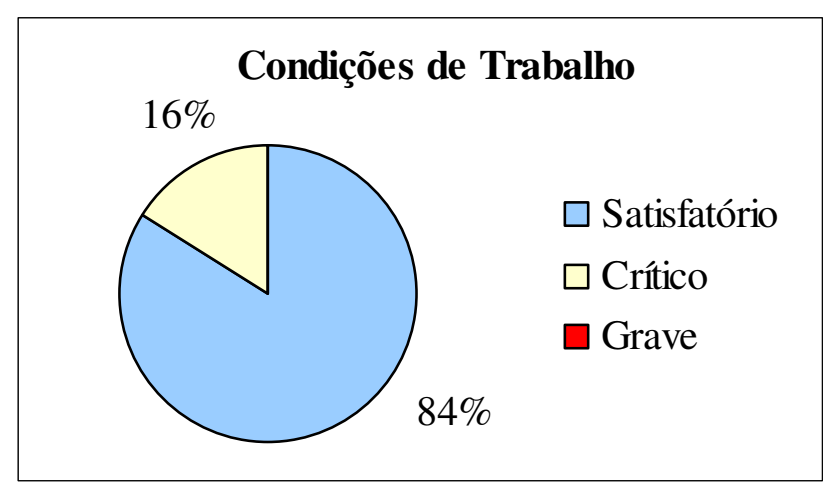

Gráfico 4 - Condições de trabalho 
Na tabela 10, destacam-se os dois itens do fator condições de trabalho que obtiveram as médias mais positivas, com o objetivo de indicar quais os elementos são os mais satisfatórios.

Tabela 10 - Condições de Trabalho: Itens mais satisfatórios

\begin{tabular}{|l|r|r|}
\hline \multicolumn{1}{|c|}{ Itens mais satisfatórios } & Média & Desvio Padrão \\
\hline As condições de trabalho são precárias & 1,36 & 0,647 \\
\hline O material de consumo é insuficiente & 1,22 & 0,580 \\
\hline
\end{tabular}

O único item que recebeu média como crítico foi "Existe muito barulho no ambiente de trabalho", com média de 2,34 e desvio padrão de 1,078, conforme tabela 11 .

Tabela 11 - Condições de Trabalho: Item crítico

\begin{tabular}{|l|r|r|}
\hline \multicolumn{1}{|c|}{ Item crítico } & Média & Desvio Padrão \\
\hline Existe muito barulho no ambiente de trabalho & 2,34 & 1,078 \\
\hline
\end{tabular}

Acredita-se que a hipótese para este resultado é a inexistência de salas fechadas e sim de estações de trabalho.

\subsubsection{Relações Socioprofissionais}

Os resultados para o fator relações socioprofissionais - gráfico 5 - demonstram que os profissionais a consideram crítica (58\%), satisfatória (42\%) e ninguém a considera grave.

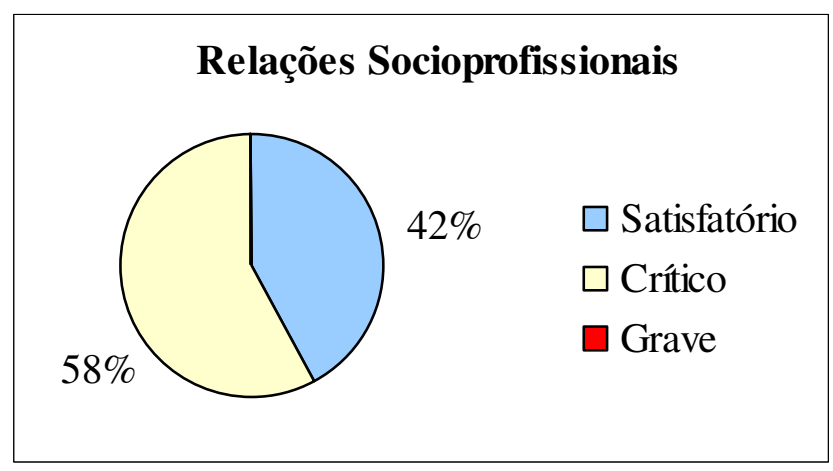

Gráfico 5 - Relações socioprofissionais 
$\mathrm{Na}$ tabela 12, destacam-se os dois itens do fator relações socioprofissionais que obtiveram as médias mais positivas, com o objetivo de indicar quais os elementos são os mais satisfatórios.

Tabela 12- Relações Socioprofissionais: Itens mais satisfatórios

\begin{tabular}{|l|r|r|}
\hline \multicolumn{1}{|c|}{ Itens mais satisfatórios } & Média & Desvio Padrão \\
\hline $\begin{array}{l}\text { As informações que preciso para executar minhas tarefas são } \\
\text { de difícil acesso }\end{array}$ & 2,03 & 0,938 \\
\hline $\begin{array}{l}\text { Falta apoio das chefias para o meu desenvolvimento } \\
\text { profissional }\end{array}$ & 2,01 & 1,113 \\
\hline
\end{tabular}

Na tabela 13, destacam-se os dois itens do fator relações socioprofissionais que obtiveram as médias mais negativas, com o objetivo de verificar quais os elementos são os mais críticos.

Tabela 13 - Relações Socioprofissionais: Itens mais críticos

\begin{tabular}{|l|r|r|}
\hline \multicolumn{1}{|c|}{ Itens mais críticos } & Média & Desvio Padrão \\
\hline Os funcionários são excluídos das decisões & 2,64 & 1,067 \\
\hline Existem disputas profissionais no local de trabalho & 2,59 & 1,122 \\
\hline
\end{tabular}

Após as análises dos fatores que compõem a Escala de Avaliação do Contexto de Trabalho - EACT verifica-se que os profissionais do Sistema Indústria o percebem como crítico, sendo que o fator "organização do trabalho" recebeu média grave, principalmente no que se refere ao cumprimento de prazos, metas, desempenho esperado e cobrança por resultado, o que indica que há necessidade de intervenção nas regras, normas e processos internos. $\mathrm{O}$ fator condições de trabalho recebeu média satisfatória e o fator relações socioprofissionais foi percebido como crítico. Para Ferreira e Mendes (2003) a análise do contexto de trabalho é um conceito fundamental para compreensão do impacto da relação entre organização e sociedade. Compreendendo o que e por que é feito, com o que é feito e com quem é feito, pode-se melhor relacionar o impacto desse novo contexto organizacional sobre as vivências de prazer e sofrimento no trabalho. 


\subsection{Resultado da Escala de Custo Humano do Trabalho (ECHT)}

A Escala de Custo Humano do Trabalho - ECHT é composta por três fatores: custo físico, cognitivo e afetivo.

A escala é de 5 pontos, onde:

\begin{tabular}{|c|c|c|c|c|}
\hline 1 & 2 & 3 & 4 & 5 \\
\hline Nunca & Pouco exigido & $\begin{array}{c}\text { Mais ou menos } \\
\text { exigido }\end{array}$ & $\begin{array}{c}\text { Bastante } \\
\text { exigido }\end{array}$ & $\begin{array}{c}\text { Totalmente } \\
\text { exigido }\end{array}$ \\
\hline
\end{tabular}

É construída com itens negativos, devendo ser analisado por fator e com base em três níveis diferentes, considerando um desvio padrão em relação ao ponto médio, cujos resultados são classificados conforme abaixo:

- Acima de 3,7 = avaliação mais negativa - grave

- Entre 2,3 e 3,69 = avaliação mais moderada - crítico

- Abaixo de 2,29 = avaliação mais positiva - satisfatório

No gráfico 6, estão destacadas as médias de cada fator que compõem o custo humano do trabalho. Os resultados de desvio padrão para todos os fatores indicam baixa dispersão de respostas.

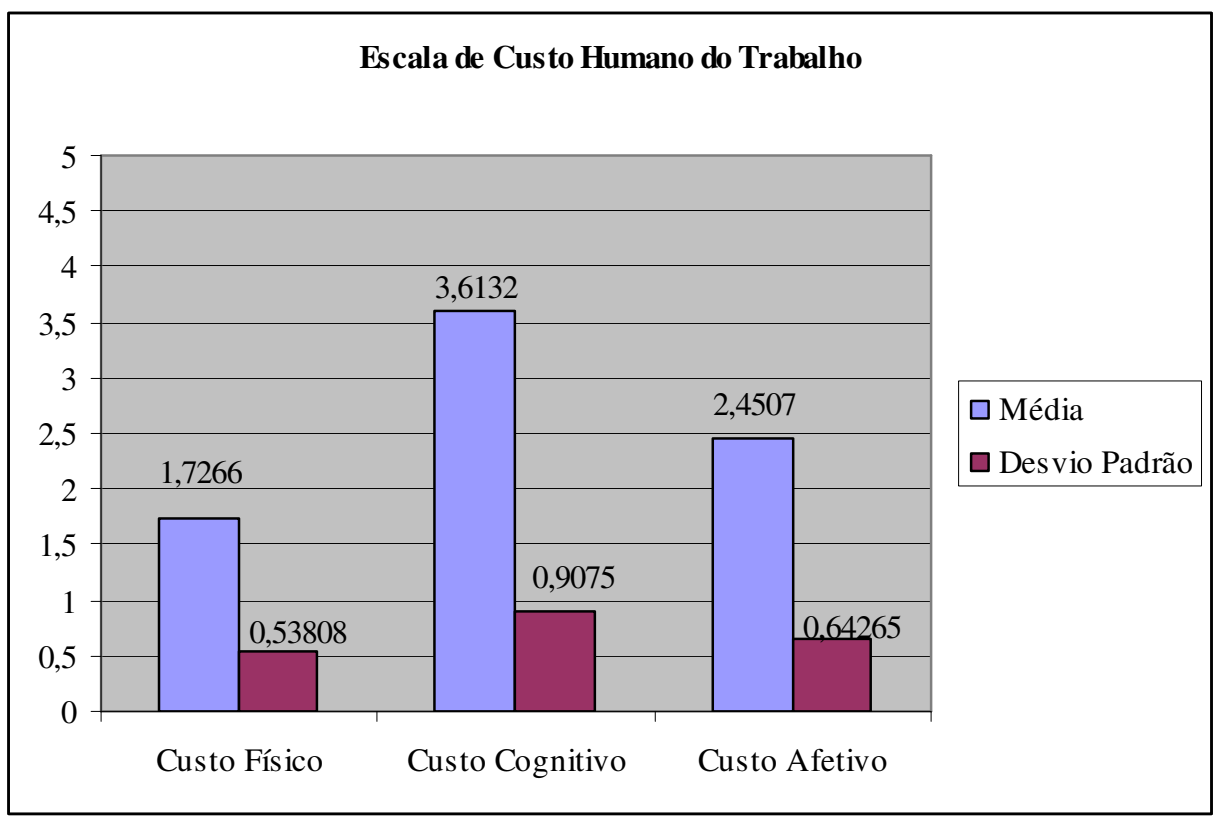

Gráfico 6: Escala de Custo Humano do Trabalho 
Nos próximos itens serão apresentados os resultados obtidos de cada fator da Avaliação do Custo Humano do Trabalho.

\subsubsection{Custo Físico}

Os resultados para custo físico - gráfico 7 - revelam que os profissionais o percebem como satisfatório (85\%) e crítico (15\%), nenhum participante o considerou como grave.

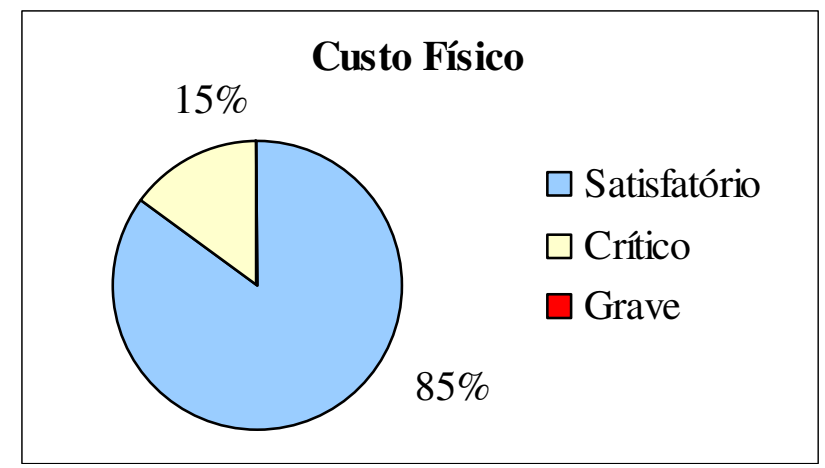

Gráfico 7 - Custo físico

$\mathrm{Na}$ tabela 14, destacam-se os dois itens do fator custo físico que obtiveram as médias mais positivas, com o objetivo de indicar quais os elementos são os mais satisfatórios.

Tabela 14 - Custo Físico: Itens mais satisfatórios

\begin{tabular}{|l|r|r|}
\hline \multicolumn{1}{|c|}{ Itens mais satisfatórios } & Média & Desvio Padrão \\
\hline Fazer esforço físico & 1,18 & 0,423 \\
\hline Ter que manusear objetos pesados & 1,16 & 0,463 \\
\hline
\end{tabular}

$\mathrm{Na}$ tabela 15, destacam-se os dois itens do fator custo físico que obtiveram as médias mais negativas, com o objetivo de verificar quais os elementos são os mais críticos. 
Tabela 15 - Custo Físico: Itens mais críticos

\begin{tabular}{|l|r|r|}
\hline \multicolumn{1}{|c|}{ Itens mais críticos } & Média & Desvio Padrão \\
\hline Usar as mãos de forma repetida & 3,11 & 1,484 \\
\hline Usar os braços de forma contínua & 2,55 & 1,446 \\
\hline
\end{tabular}

Acredita-se que a média crítica para esses fatores deve-se ao trabalho de digitação realizado pelos participantes.

\subsubsection{Custo Cognitivo}

Os resultados para custo cognitivo - gráfico 8 - demonstram que os profissionais o consideram grave (49\%), crítico (43\%) e satisfatório (8\%).

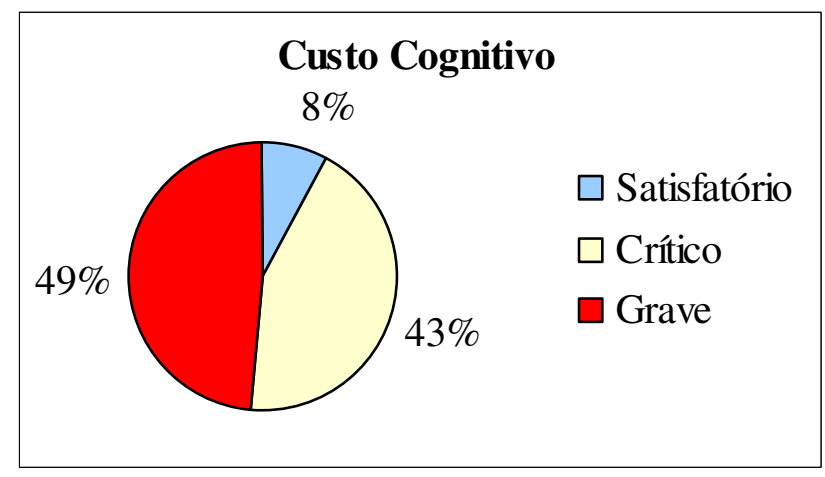

Gráfico 8 - Custo Cognitivo

Na tabela 16, destacamos o único item do fator custo cognitivo que obteve média positiva, considerado o mais satisfatório.

Tabela 16 - Custo Cognitivo: Item mais satisfatório

\begin{tabular}{|l|r|r|}
\hline \multicolumn{1}{|c|}{ Item mais satisfatório } & Média & Desvio Padrão \\
\hline Desenvolver macetes & 2,24 & 1,187 \\
\hline
\end{tabular}


Na tabela 17, destacam-se os dois itens do fator custo cognitivo que obtiveram as médias mais negativas, com o objetivo de verificar quais os elementos são os mais graves.

Tabela 17 - Custo Cognitivo: Itens mais graves

\begin{tabular}{|l|r|r|}
\hline \multicolumn{1}{|c|}{ Itens mais graves } & Média & Desvio Padrão \\
\hline Ser obrigado a lidar com imprevistos & 4,00 & 1,071 \\
\hline Ter que resolver problemas & 3,99 & 1,064 \\
\hline
\end{tabular}

Pode-se observar que os itens considerados como mais graves são correlacionados, pois ter que resolver problemas está muito próximo de ser obrigado a lidar com imprevistos. Acredita-se que tal resultado deva-se as adequações internas e as constantes mudanças de normas e de procedimentos.

\subsubsection{Custo Afetivo}

Os resultados para custo afetivo - gráfico 9 - revelam que os profissionais o percebem como crítico (58\%), satisfatório (38\%) e grave apenas (4\%).

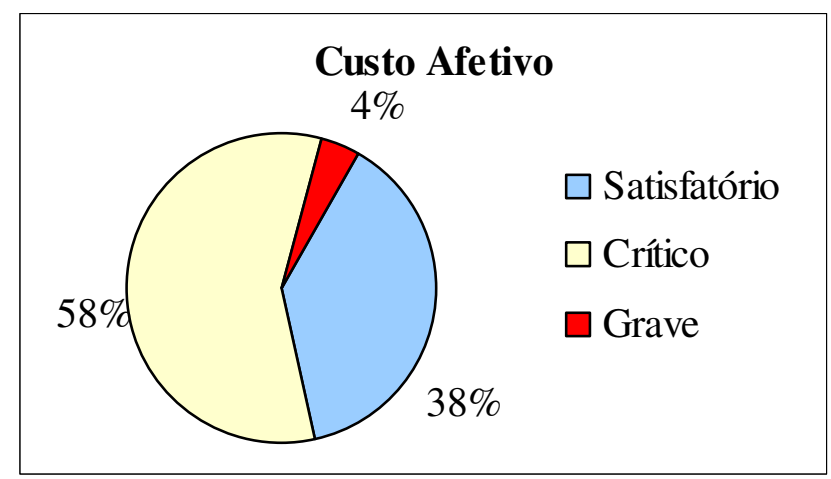

Gráfico 9 - Custo afetivo

Na tabela 18, destacam-se os dois itens do fator custo afetivo que obtiveram as médias mais positivas, com o objetivo de indicar quais elementos são os mais satisfatórios. 
Tabela 18 - Custo Afetivo: Itens mais satisfatórios

\begin{tabular}{|l|r|r|}
\hline \multicolumn{1}{|c|}{ Itens mais satisfatórios } & Média & Desvio Padrão \\
\hline Ser obrigado a elogiar as pessoas & 1,64 & 0,844 \\
\hline Ser submetido a constrangimentos & 1,57 & 0,914 \\
\hline
\end{tabular}

Na tabela 19, destacam-se os dois itens do fator custo afetivo que obtiveram as médias mais negativas, com o objetivo de verificar quais elementos são os mais graves.

Tabela 19 - Custo Afetivo: Itens mais graves

\begin{tabular}{|l|r|r|}
\hline \multicolumn{1}{|c|}{ Itens mais graves } & Média & Desvio Padrão \\
\hline Ter controle das emoções & 3,53 & 1,039 \\
\hline Ter que lidar com ordens contraditórias & 3,04 & 1,089 \\
\hline
\end{tabular}

Os resultados obtidos revelam que o custo humano do trabalho dos profissionais do Sistema Indústria é percebido como crítico, pois os fatores custo cognitivo e custo afetivo apresentam médias críticas, sendo que o custo cognitivo ficou muito próximo da avaliação grave, o que indica que há necessidade de alguma intervenção, especialmente nos dois itens: "ser obrigado a lidar com imprevistos" e "ter que resolver problemas". Segundo Mendes (2007) o custo cognitivo, significa dispêndio intelectual para aprendizagem, resolução de problemas e tomada de decisão no trabalho. O fator "custo físico" recebeu a média mais baixa, mas um dado interessante levantado na pesquisa é que os homens o percebem mais que as mulheres.

\subsection{Resultado da Escala de Indicadores de Prazer e Sofrimento no Trabalho (EIPST)}

A Escala de Indicadores de Prazer-Sofrimento no Trabalho - EIPST é composta por quatro fatores: dois avaliam o prazer através dos itens - realização profissional e liberdade de 
expressão e os outros dois avaliam o sofrimento no trabalho - falta de reconhecimento e liberdade de expressão.

A escala é de 7 pontos, e tem por objetivo avaliar nos últimos seis meses a ocorrência das vivências dos indicadores de prazer-sofrimento, onde:

\begin{tabular}{|c|c|c|c|c|c|c|}
\hline 0 & 1 & 2 & 3 & 4 & 5 & 6 \\
\hline $\begin{array}{c}\text { Nenhuma } \\
\text { vez }\end{array}$ & Uma vez & Duas vezes & Três vezes & $\begin{array}{c}\text { Quatro } \\
\text { vezes }\end{array}$ & $\begin{array}{c}\text { Cinco } \\
\text { vezes }\end{array}$ & $\begin{array}{c}\text { Seis ou } \\
\text { mais vezes }\end{array}$ \\
\hline
\end{tabular}

Nos próximos itens serão apresentados os resultados obtidos de cada fator das vivências de prazer e de sofrimento.

\subsubsection{Vivências de Prazer}

Para os fatores do prazer, considerando que os itens são positivos, a análise é diferente das escalas anteriores. Deve ser feita também por fator, e como é de 7 pontos, para melhor especificação e qualificação da freqüência com que é experimentada a vivência, deve ser classificada em três níveis diferentes, com um desvio padrão para cada um, conforme abaixo:

- Acima de 4,0 = avaliação mais positiva, satisfatório

- Entre 3,9 e 2,1 = avaliação moderada - crítico

- Abaixo de 2,0 = avaliação para raramente - grave

No gráfico 10, estão destacadas as médias de cada fator que compõem as vivências de prazer no trabalho. Os resultados de desvio padrão para todos os fatores indicam baixa dispersão de respostas. 


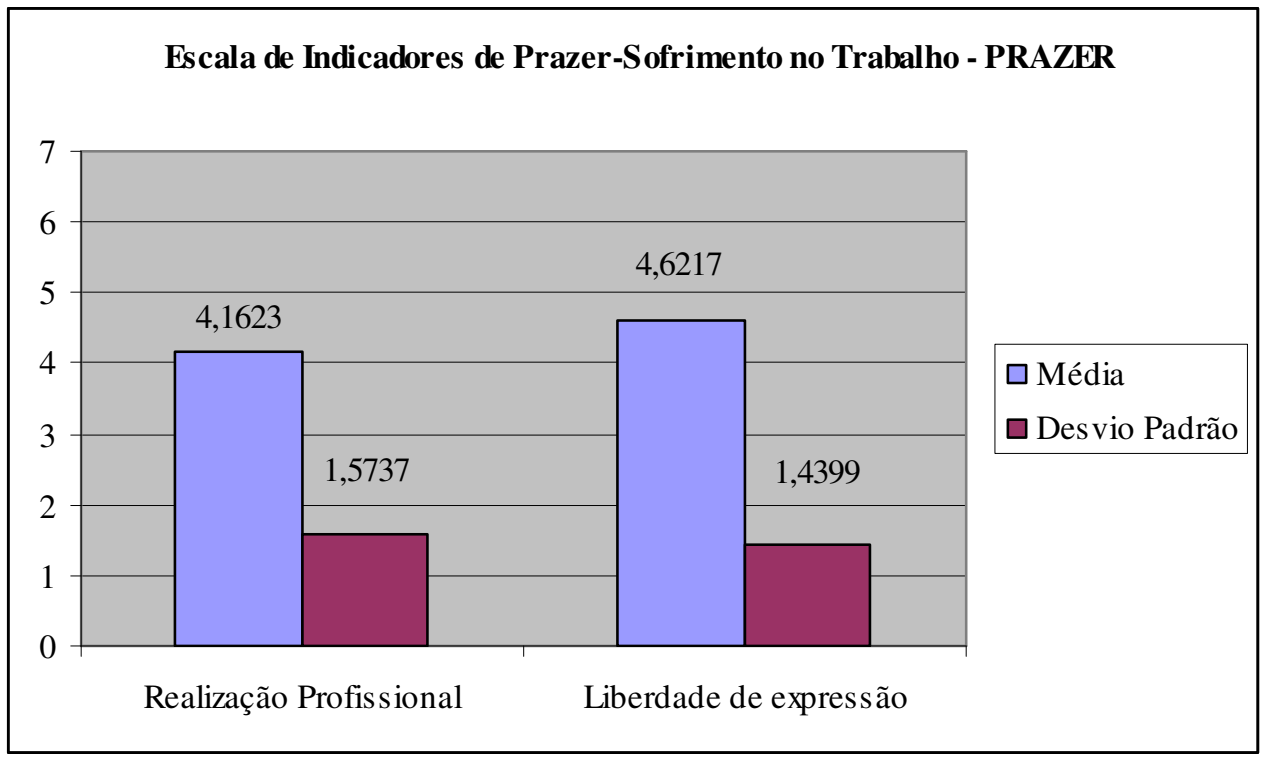

Gráfico 10 - Escala de Indicadores de Prazer-Sofrimento no Trabalho - PRAZER

Nos próximos itens serão apresentados os resultados obtidos dos dois fatores dos indicadores de prazer no trabalho.

\subsubsection{Realização Profissional}

Os resultados para realização profissional - gráfico 11 - revelam que os profissionais o percebem como satisfatório (55\%), crítico (32\%) e grave (13\%).

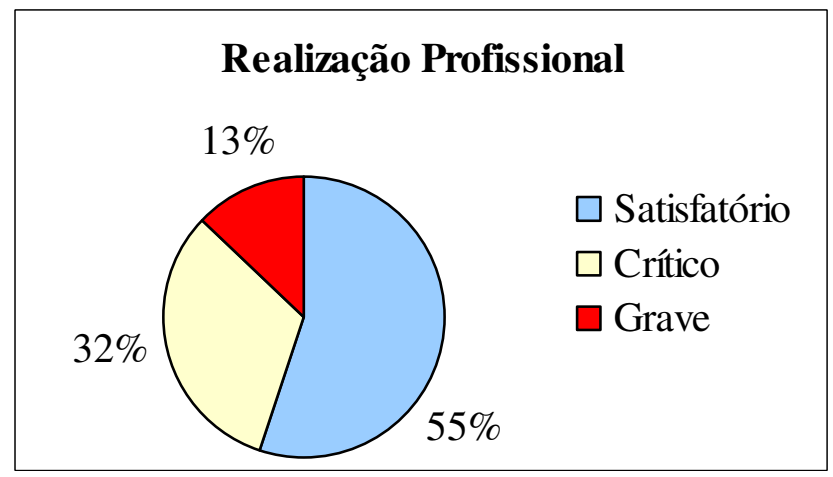

Gráfico 11 - Realização Profissional 
Na tabela 20, destacam-se os dois itens do fator realização profissional que obtiveram as médias mais positivas, com o objetivo de indicar quais os elementos são os mais satisfatórios.

Tabela 20 - Realização Profissional: Itens mais satisfatórios

\begin{tabular}{|l|r|r|}
\hline \multicolumn{1}{|c|}{ Itens mais satisfatórios } & Média & Desvio Padrão \\
\hline Orgulho pelo que faço & 4,64 & 1,647 \\
\hline Satisfação & 4,38 & 1,781 \\
\hline
\end{tabular}

Na tabela 21, destacam-se os dois itens do fator realização profissional que obtiveram as médias mais negativas, com o objetivo de verificar quais os elementos são os mais críticos.

Tabela 21 - Realização Profissional: Itens mais críticos

\begin{tabular}{|l|r|r|}
\hline \multicolumn{1}{|c|}{ Itens mais críticos } & Média & Desvio Padrão \\
\hline Valorização & 3,84 & 1,884 \\
\hline Reconhecimento & 3,67 & 1,942 \\
\hline
\end{tabular}

Os resultados revelam que os profissionais do Sistema Indústria sentem orgulho e satisfação pelo que fazem, mas não se sentem reconhecidos e valorizados pelo trabalho realizado.

\subsubsection{Liberdade de Expressão}

Os resultados para o fator liberdade de expressão - gráfico 12 - revelam que os profissionais o percebem como satisfatório (72\%), crítico (23\%) e grave (5\%). 


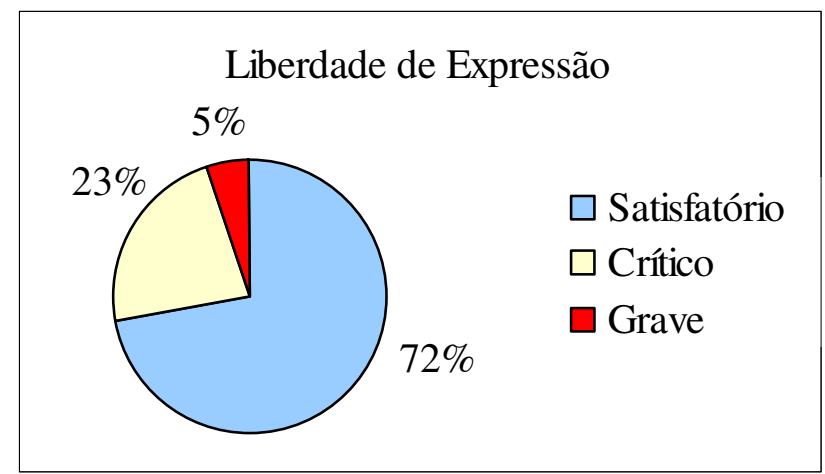

Gráfico 12 - Liberdade de expressão

Na tabela 22, destacam-se os dois itens do fator liberdade de expressão que obtiveram as médias mais positivas, com o objetivo de indicar quais os elementos são os mais satisfatórios.

Tabela 22 - Liberdade de Expressão: Itens mais satisfatórios

\begin{tabular}{|l|r|r|}
\hline \multicolumn{1}{|c|}{ Itens mais satisfatórios } & Média & Desvio Padrão \\
\hline Liberdade para falar sobre o meu trabalho com os colegas & 4,93 & 1,723 \\
\hline Solidariedade entre os colegas & 4,92 & 1,623 \\
\hline
\end{tabular}

Na tabela 23, destacam-se os dois itens do fator liberdade de expressão que obtiveram as médias menos satisfatórias.

Tabela 23 - Liberdade de Expressão: Itens menos satisfatórios

\begin{tabular}{|l|r|r|}
\hline \multicolumn{1}{|c|}{ Itens menos satisfatórios } & Média & Desvio Padrão \\
\hline Liberdade para falar sobre o meu trabalho com as chefias & 4,30 & 2,072 \\
\hline Liberdade com a chefia para negociar o que precisa & 4,20 & 1,987 \\
\hline
\end{tabular}

Os resultados obtidos revelam que as vivências de prazer no trabalho dos profissionais do Sistema Indústria são satisfatórias. Os profissionais sentem liberdade para falar sobre o seu trabalho com os colegas e são solidários entre si. O item menos satisfatório demonstra que há dificuldade em negociar com as chefias.

O fator liberdade de expressão apresentou média mais satisfatória, que segundo 
Mendes (2007) é a vivência de liberdade para pensar, organizar e falar sobre o seu trabalho.

\subsubsection{Vivências de Sofrimento}

Para os fatores do sofrimento, considerando que os itens são negativos, a análise deve ser feita, conforme abaixo:

- Acima de 4,0 = avaliação mais negativa - grave

- Entre 3,9 e 2,1 = avaliação moderada - crítico

- Abaixo de 2,0 = avaliação menos negativa - satisfatório

No gráfico 13, estão destacadas as médias de cada fator que compõem as vivências de sofrimento no trabalho. Os resultados de desvio padrão para todos os fatores indicam baixa dispersão de respostas.

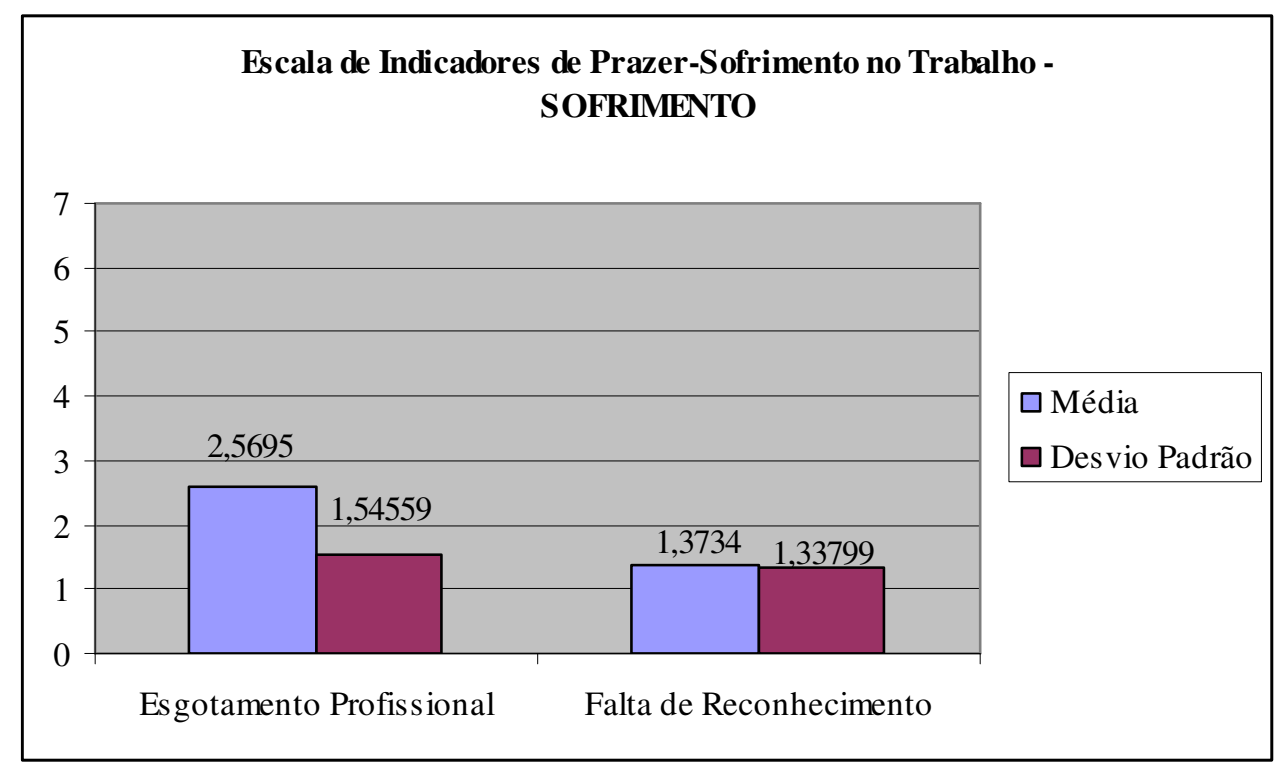

Gráfico 13 - Escala de Indicadores de Prazer-Sofrimento no Trabalho - SOFRIMENTO

Nos próximos itens serão apresentados os resultados obtidos dos dois fatores dos indicadores de sofrimento no trabalho. 


\subsubsection{Esgotamento Profissional}

Os resultados para esgotamento profissional - gráfico 14 - revelam que os profissionais o percebem como crítico (43\%), satisfatório (41\%) e grave (16\%).

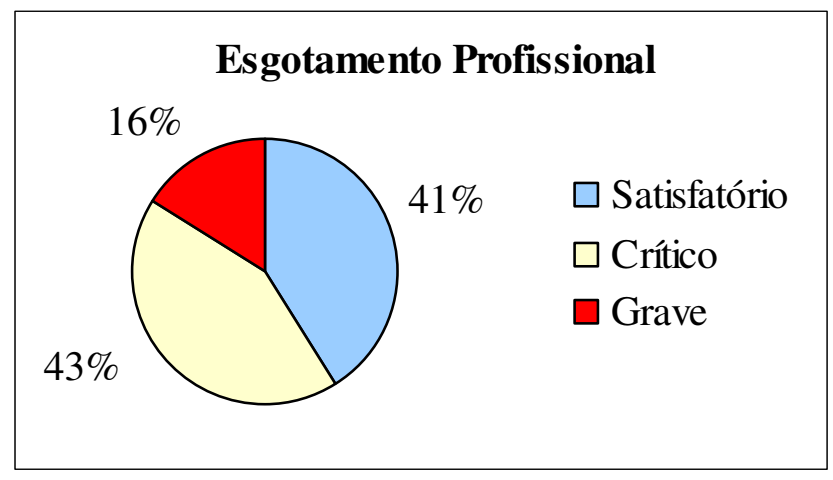

Gráfico 14 - Esgotamento Profissional

$\mathrm{Na}$ tabela 24, destacam-se os dois itens do fator esgotamento profissional que obtiveram as médias mais positivas, com o objetivo de indicar quais os elementos são os mais satisfatórios.

Tabela 24 - Esgotamento Profissional: Itens mais satisfatórios

\begin{tabular}{|l|r|r|}
\hline \multicolumn{1}{|c|}{ Itens mais satisfatórios } & Média & Desvio Padrão \\
\hline Insegurança & 2,11 & 1,922 \\
\hline Medo & 1,55 & 1,843 \\
\hline
\end{tabular}

$\mathrm{Na}$ tabela 25, destacam-se os dois itens do fator esgotamento profissional que obtiveram as médias menos satisfatórias.

Tabela 25 - Esgotamento Profissional: Itens menos satisfatórios

\begin{tabular}{|l|r|r|}
\hline \multicolumn{1}{|c|}{ Itens menos satisfatórios } & Média & Desvio Padrão \\
\hline Estresse & 3,34 & 1,997 \\
\hline Sobrecarga & 3,20 & 1,918 \\
\hline
\end{tabular}

Os resultados revelam que os profissionais do Sistema Indústria sentem a sobrecarga 
de trabalho e o estresse.

\subsubsection{Falta de Reconhecimento}

Os resultados para falta de reconhecimento - gráfico 15 - revelam que os profissionais o percebem como satisfatório (75\%), crítico $(21 \%)$ e grave $(4 \%)$.

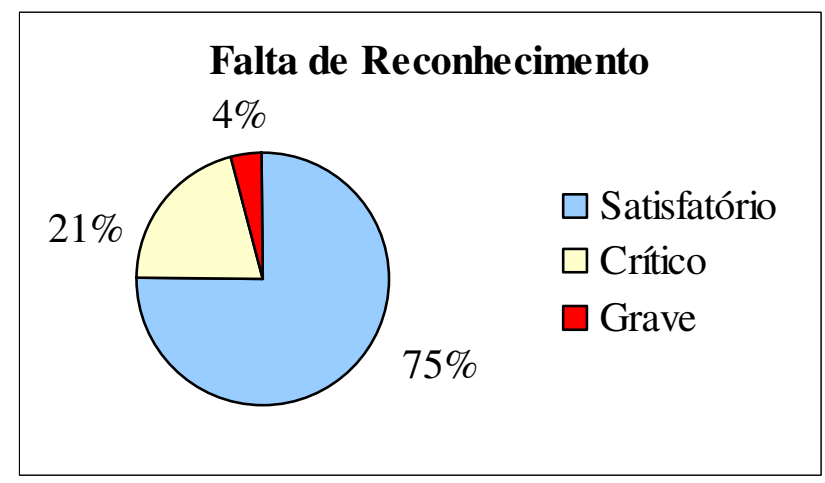

Gráfico 15 - Falta de Reconhecimento

$\mathrm{Na}$ tabela 26, destacam-se os dois itens do fator falta de reconhecimento que obtiveram as médias mais positivas, com o objetivo de indicar quais os elementos são os mais satisfatórios.

Tabela 26 - Falta de Reconhecimento: Itens mais satisfatórios

\begin{tabular}{|l|r|r|}
\hline \multicolumn{1}{|c|}{ Itens mais satisfatórios } & Média & Desvio Padrão \\
\hline Inutilidade & 0,71 & 1,294 \\
\hline Discriminação & 0,62 & 1,316 \\
\hline
\end{tabular}

$\mathrm{Na}$ tabela 27, destacam-se os dois itens do fator falta de reconhecimento que obtiveram as médias menos satisfatórias. 
Tabela 27 - Falta de Reconhecimento: Itens menos satisfatórios

\begin{tabular}{|l|r|r|}
\hline \multicolumn{1}{|c|}{ Itens menos satisfatórios } & Média & Desvio Padrão \\
\hline Falta de reconhecimento do meu desempenho & 2,28 & 2,050 \\
\hline Falta de reconhecimento do meu esforço & 2,24 & 1,945 \\
\hline
\end{tabular}

Os resultados revelam que os profissionais do Sistema Indústria sentem a falta de reconhecimento do seu desempenho e seu esforço.

Os resultados obtidos revelam que as vivências de sofrimento no trabalho dos profissionais do Sistema Indústria estão entre crítica e satisfatória, sendo que o fator "Esgotamento Profissional" recebeu média crítica, que segundo Mendes (2007) representa a vivência de frustração, insegurança, inutilidade, desgaste e estresse no trabalho.

\subsection{Resultado da Escala de Avaliação dos Danos Relacionados ao Trabalho (EADRT)}

A Escala de Indicadores de Avaliação dos Danos Relacionados ao Trabalho é composta por três fatores: danos físicos, psicológicos e sociais.

A escala é de 7 pontos, e tem por objetivo avaliar nos últimos três meses os danos provocados pelo trabalho, onde:

\begin{tabular}{|c|c|c|c|c|c|c|}
\hline 0 & 1 & 2 & 3 & 4 & 5 & 6 \\
\hline $\begin{array}{c}\text { Nenhuma } \\
\text { vez }\end{array}$ & Uma vez & Duas vezes & Três vezes & $\begin{array}{c}\text { Quatro } \\
\text { vezes }\end{array}$ & $\begin{array}{c}\text { Cinco } \\
\text { vezes }\end{array}$ & $\begin{array}{c}\text { Seis ou } \\
\text { mais vezes }\end{array}$ \\
\hline
\end{tabular}

A análise dessa escala deve ser realizada de modo diferente das demais. Os itens propostos retratam situações muito graves relacionadas à saúde: sua aparição e repetição num nível moderado já significa adoecimento. Por isso, o ponto médio dessa escala é desdobrado em dois intervalos com variação de um desvio padrão.

Assim os resultados devem ser classificados em quatro níveis:

- Acima de 4,1 = avaliação mais negativa, presença de doenças ocupacionais;

- Entre 3,1 e 4,0 = avaliação moderada para freqüente, grave; 
- Entre 2,0 e 3,0 = avaliação moderada, crítico;

- Abaixo de 1,9 = avaliação mais positiva, suportável.

No gráfico 16, estão destacadas as médias de cada fator que compõem a Escala de Avaliação dos Danos Relacionados ao Trabalho - EADRT. Os resultados de desvio padrão para todos os fatores indicam baixa dispersão de respostas.

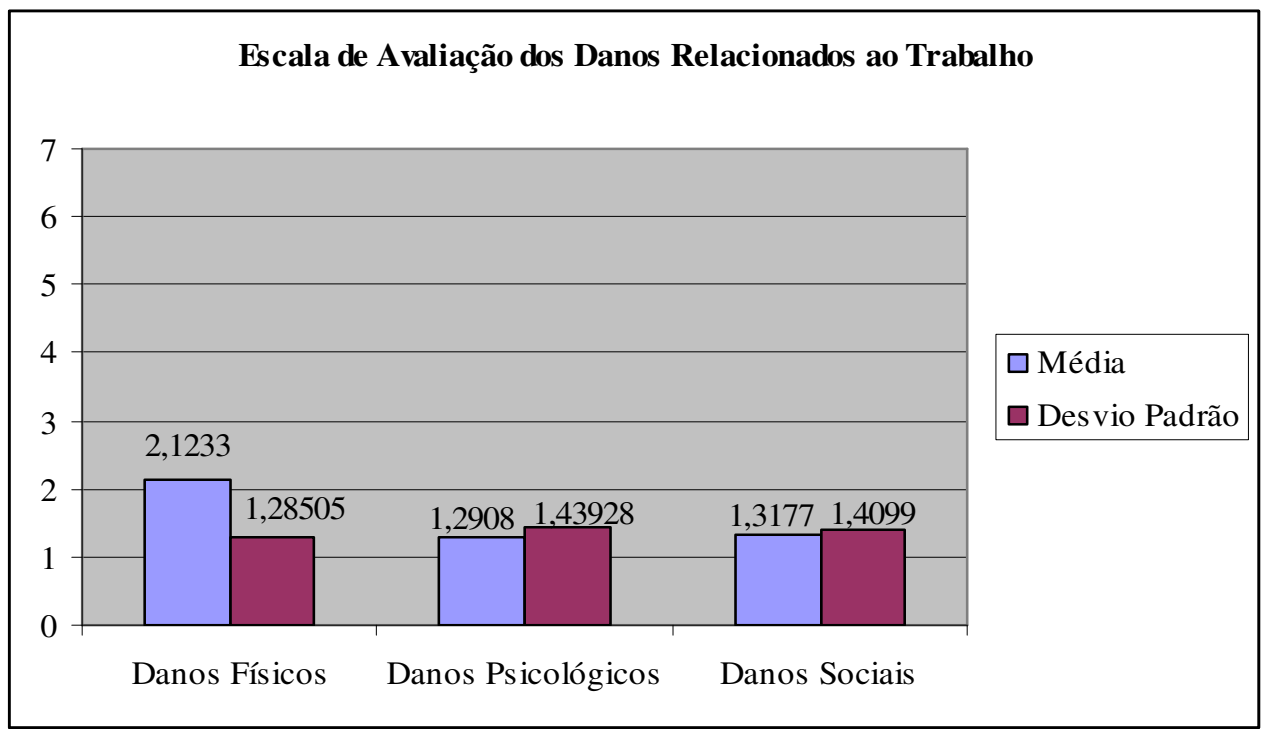

Gráfico 16: Escala de Avaliação dos Danos Relacionados ao Trabalho

Nos próximos itens serão apresentados os resultados obtidos de cada fator da Avaliação dos Danos Relacionados ao Trabalho.

\subsubsection{Danos Físicos}

Os resultados para danos físicos - gráfico 17 - revelam que os profissionais o percebem como satisfatório (51\%), crítico (44\%) e grave $(5 \%)$. 


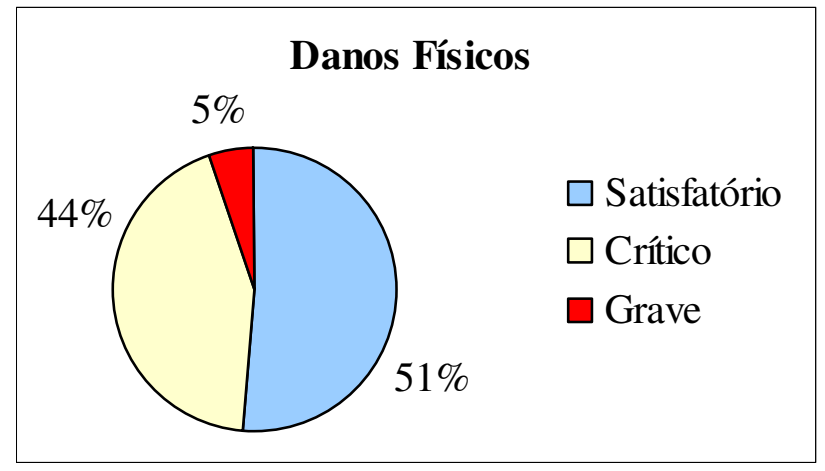

Gráfico 17 - Danos Físicos

Na tabela 28, destacam-se os dois itens do fator danos físicos que obtiveram as médias mais positivas, com o objetivo de indicar quais os elementos são os mais satisfatórios.

Tabela 28 - Danos Físicos: Itens mais satisfatórios

\begin{tabular}{|l|r|r|}
\hline \multicolumn{1}{|c|}{ Itens mais satisfatórios } & Média & Desvio Padrão \\
\hline Distúrbios respiratórios & 0,93 & 1,652 \\
\hline Distúrbios auditivos & 0,75 & 1,576 \\
\hline
\end{tabular}

Na tabela 29, destacam-se os dois itens do fator danos físicos que obtiveram as médias mais negativas, com o objetivo de verificar quais os elementos são os mais graves.

Tabela 29 - Danos Físicos: Itens mais graves

\begin{tabular}{|l|r|r|}
\hline \multicolumn{1}{|c|}{ Itens mais graves } & Média & Desvio Padrão \\
\hline Dores nas costas & 3,58 & 2,137 \\
\hline Dores no corpo & 3,42 & 2,211 \\
\hline
\end{tabular}

Acredita-se que a média grave para esses fatores deve-se ao tipo de trabalho realizado pelos participantes (digitação e reuniões). 


\subsubsection{Danos Psicológicos}

Os resultados para danos psicológicos - gráfico 18 - revelam que os profissionais o percebem como satisfatório (82\%), crítico $(12 \%)$ e grave $(6 \%)$.

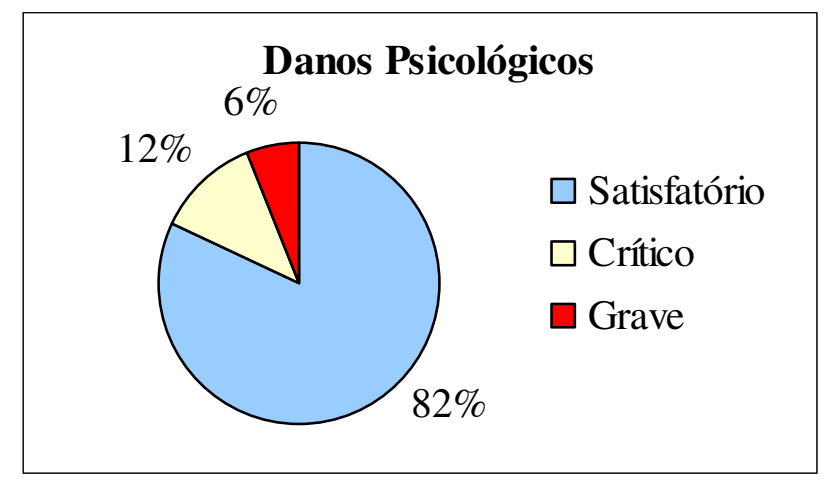

Gráfico 18 - Danos Psicológicos

Na tabela 30, destacam-se os dois itens do fator danos psicológicos que obtiveram as médias mais positivas, com o objetivo de indicar quais os elementos são os mais satisfatórios.

Tabela 30 - Danos Psicológicos: Itens mais satisfatórios

\begin{tabular}{|l|r|r|}
\hline \multicolumn{1}{|c|}{ Itens mais satisfatórios } & Média & Desvio Padrão \\
\hline Sentimento de desamparo & 0,97 & 1,665 \\
\hline Sensação de abandono & 0,97 & 1,673 \\
\hline
\end{tabular}

Na tabela 31, destacam-se os dois itens do fator danos psicológicos que obtiveram as médias mais negativas, com o objetivo de verificar quais os elementos são os mais críticos.

Tabela 31 - Danos Psicológicos: Itens mais críticos

\begin{tabular}{|l|r|r|}
\hline \multicolumn{1}{|c|}{ Itens mais críticos } & Média & Desvio Padrão \\
\hline Tristeza & 1,72 & 1,997 \\
\hline Mau-humor & 1,67 & 1,799 \\
\hline
\end{tabular}




\subsubsection{Danos Sociais}

Os resultados para danos sociais - gráfico 19 - revelam que os profissionais o percebem como satisfatório (78\%), crítico (18\%) e grave (4\%).

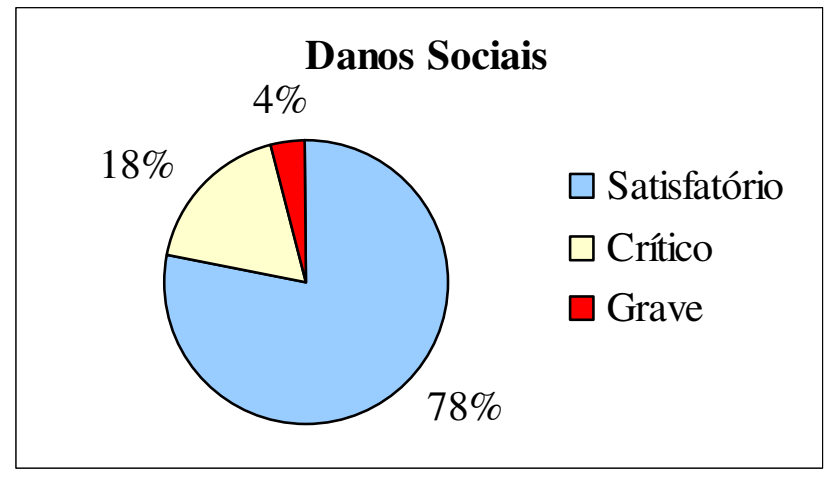

Gráfico 19 - Danos Sociais

Na tabela 32, destacam-se os dois itens do fator danos sociais que obtiveram as médias mais positivas, com o objetivo de indicar quais os elementos são os mais satisfatórios.

Tabela 32 - Danos Sociais: Itens mais satisfatórios

\begin{tabular}{|l|r|r|}
\hline \multicolumn{1}{|c|}{ Itens mais satisfatórios } & Média & Desvio Padrão \\
\hline Insensibilidade em relação aos colegas & 0,96 & 1,562 \\
\hline Dificuldade com os amigos & 0,93 & 1,668 \\
\hline
\end{tabular}

Somente o item "Vontade de ficar sozinho" recebeu média crítica, conforme tabela 33.

Tabela 33 - Danos Sociais: Item mais crítico

\begin{tabular}{|l|r|r|}
\hline \multicolumn{1}{|c|}{ Item mais crítico } & Média & Desvio Padrão \\
\hline Vontade de ficar sozinho & 2,04 & 2,056 \\
\hline
\end{tabular}

Os resultados obtidos revelam que os profissionais do Sistema Indústria, percebem os resultados dos danos relacionados ao trabalho como críticos e suportáveis. Sendo que o fator "danos físicos" recebeu média crítica e que as mulheres e as pessoas entre 32 e 40 anos são as 
mais atingidas. Segundo Mendes (2007), os danos físicos estão relacionados com as dores no corpo e distúrbios biológicos. 


\section{Conclusão}

O objetivo geral deste estudo foi o de identificar os fatores que determinam o processo de saúde-adoecimento dos profissionais da Área Compartilhada das Entidades Nacionais do Sistema Indústria. Nessa perspectiva, os resultados da pesquisa puderam evidenciar a influência existente entre o contexto de trabalho e as vivências de prazer e sofrimento. Além disso, como objetivos específicos, procurou-se diagnosticar os riscos de adoecimento no trabalho a partir do contexto de trabalho, do custo humano de trabalho, do custo prazer e sofrimento no trabalho, dos danos relacionados ao trabalho e subsidiar o planejamento de ações institucionais para manutenção e/ou melhoria do Programa de Qualidade de Vida no Trabalho do Sistema Indústria.

Após análise das quatro escalas que compõem o instrumento de pesquisa - Inventário sobre Trabalho e Riscos de Adoecimento - ITRA, verificou-se que um dos fatores que mais revela sofrimento no trabalho está no aspecto cognitivo, pois a natureza do trabalho requer decisões e resoluções de problemas a todo instante, sem tempo para planejamento e execução de atividades em longo prazo. A partir da realidade da Entidade é possível compreender que os profissionais perdem suas defesas em relação a isso porque as metas precisam ser atingidas e nem sempre as condições oferecidas são suficientes. O custo físico é percebido como satisfatório.

A organização do trabalho e as relações socioprofissionais, são vistas como críticas, pois há fiscalização do desempenho, cobrança por resultado, pressão de prazos e disputas profissionais no local de trabalho. Acredita-se que tal resultado deve-se à implantação da nova política de avaliação de desempenho por resultado e metas. As condições de trabalho foram consideradas satisfatórias, o único item que merece atenção é o barulho no ambiente de trabalho.

Os danos relacionados ao trabalho foram percebidos como suportáveis. Somente o item "danos físicos" foi considerado crítico, com maior incidência de queixas de dores nas costas e no corpo. Dado que precisa ser pesquisado futuramente, pois os profissionais contam com ginástica laboral, fisioterapeuta e programa de correção pastoral in company.

Os indicadores de prazer-sofrimento de modo geral foram considerados satisfatórios. As vivências de prazer demonstram que há satisfação e orgulho pelo trabalho realizado, assim como a liberdade para falar sobre o trabalho com os colegas e alto grau de solidariedade entre 
eles.

Nas vivências de sofrimento o esgotamento profissional foi percebido como crítico, sendo que o estresse e a sobrecarga de trabalho são os fatores que podem causar o adoecimento dos profissionais do Sistema Indústria.

Neste estudo não foi percebida nenhuma estratégia defensiva coletiva, somente as individuais.

Com base nos resultados, demonstra-se que o contexto de trabalho estudado apresenta indicadores de saúde e adoecimento. Os indicadores de saúde aparecem na satisfação e orgulho pelo trabalho realizado e solidariedade entre os colegas. Os indicadores de adoecimento surgem na sobrecarga de trabalho, no estresse e na falta de reconhecimento pelo esforço e desempenho dos profissionais.

Prazer e sofrimento no contexto de trabalho fazem parte de uma dinâmica própria à vida. Sofrer pode ser também uma oportunidade para a obtenção do prazer, segundo a abordagem da Psicodinâmica. Contudo, como lidar com esse sofrimento é o que definirá a tendência para uma descompensação ou equilíbrio psicológicos.

Pelas razões apontadas no resultado da presente pesquisa recomenda-se que a estrutura atual do Programa de Qualidade de Vida no Trabalho seja mantida, sugere-se apenas alguns ajustes na diretriz "saúde preventiva", que apesar de ter seu foco na prevenção e promoção da saúde dos trabalhadores, torna-se necessária que se faça algumas melhoria com vistas ao aprimoramento da saúde psíquica e emocional dos profissionais do Sistema Indústria.

\section{REFERÊNCIAS}

CNI. Plano Estratégico do Sistema Indústria 2006-2010. Brasília: CNI, 2006. 
DEJOURS, C. A banalização da injustiça social. São Paulo: FGV, 1999.

DRUCKER, P.F. Desafios gerenciais para o século XXI. São Paulo: Pioneira, 2000.

FERNANDES, E. Qualidade de vida no trabalho: como medir para melhorar. Salvador: Casa da Qualidade, 1996.

FERREIRA, M.C.; FREIRE O.N. Carga de trabalho e rotatividade na função de frentista. In: Revista de Administração Contemporânea - RAC. Curitiba, 2001.

FERREIRA, M.C.; MENDES A.M. Trabalho e riscos de adoecimento: o caso dos auditores-fiscais da previdência social brasileira. Brasília: Ler, Pensar e Agir, 2003.

FREITAS, L.G. Saúde e processo de adoecimento no trabalho dos professores em ambiente virtual. Dissertação (Doutorado em Psicologia) - Instituto de Psicologia Social Universidade de Brasília, Brasília, 2006.

LEME, P.R. Análise do significado do Programa de Demissões Voluntárias do Banco do Brasil. Dissertação de mestrado - Universidade Federal do Rio Grande do Sul, Porto Alegre, 2000 .

LIMONGI-FRANÇA, A.C. Fatores críticos da gestão de QVT: retrospectiva conceitual. In: Qualidade de Vida no Trabalho - QVT. Conceitos e práticas nas empresas da sociedade pós-industrial. 2.ed. São Paulo: Atlas, 2004. cap.2.

LIMONGI-FRANÇA, A.C; Arellano, E.B. Qualidade de vida no trabalho. In: As pessoas na organização. 3.ed. São Paulo: Gente, 2002.

MENDES, A. M. Uma proposta para pesquisa e gestão da qualidade de vida no trabalho. POL - Psicologia Online, maio 2004. Disponível em: http://www.pol.org.br/publicacoes. Acesso em: 22 out. 2007.

MENDES, A. M. Psicodinâmica do Trabalho: teoria, método e pesquisas. 1.ed. São Paulo: Casa Psi, 2007.

MENDES, A. M.; Abrahão J.I. A influência da organização do trabalho nas vivências de prazer-sofrimento do trabalhador: uma abordagem psicodinâmica. Revista Psicologia: Teoria e pesquisa. V.26, n.2, p. 179-184, 1996.

MENDES, A. M. B.; SILVA, R. R. Prazer e sofrimento no trabalho dos líderes religiosos numa organização protestante neopentecostal e noutra tradicional. PsicoUSF, jun. 2006, vol.11, no.1.ISSN 1413-8271. 
NAHAS, M.V. A Era do estilo de Vida. In: Atividade Física, Saúde e Qualidade de Vida Conceitos e Sugestões para um Estilo de Vida Ativo. 4.ed. Londrina: Midiograf, 2006. cap.1.

OGATA, A.; LEANDRO A.M. A Qualidade de Vida no Trabalho. BANAS Online, p.25 Fevereiro 2008. Disponível em: http://www.banasqualidade.com.br. Acesso em: 15 mar 2008.

OLIVEIRA, P.M.; LIMONGI-FRANÇA, A.C.- Avaliação da gestão de programas de Qualidade de Vida no Trabalho. RAE-eletrônica, v. 4, n. 1, Art. 9, jan./jul. 2005.

ROCHA, S.R.A. O pior é não ter mais profissão, bate uma tristeza profunda: sofrimento, distúrbios osteomusculares relacionados ao trabalho e depressão em bancários. Dissertação de mestrado - Universidade de Brasília, Brasília, 2003.

SEIDL, E.M.F.; ZANNON, C.M.L.C. Qualidade de vida e saúde: aspectos conceituais e metodológicos. Cad. Saúde Pública, Rio de Janeiro, 20 (2):580-588, mar-abr, 2004.

SISTEMA INDÚSTRIA; Programa Qualidade de Vida. SESI/DN, 2002.

SISTEMA INDÚSTRIA; Resultado Programa de Controle Médico de Saúde Ocupacional. Área Compartilhada de Recursos Humanos, 2005.

VERGARA, S. C. Começando a definir a metodologia. In: Projetos e relatórios de pesquisa em Administração. 3. ed. São Paulo: Atlas, 2000. cap. 4. 


\section{APÊNDICE A}

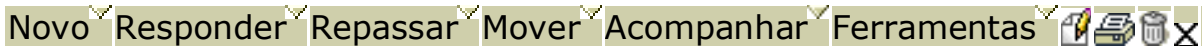

De: $\quad X X X X X X X X X X X X X X X X X X X$

Para: TODOS - ASC

Data: Quinta-feira, 07 de fevereiro de 2008 12:17

Assunto: Colaboração para a colega Ludmilla/ACRH: responder questionário

Histórico: $\quad$ Esta mensagem foi encaminhada.

Prezado(a),

A nossa colega Ludmilla de Sá Moraes Telles Silva/ACRH está realizando uma pesquisa para a conclusão da pós-graduação na Universidade de Brasília e precisa de nossa colaboração para o preenchimento do questionário - Inventário sobre Trabalho e Riscos de Adoecimento - ITRA, até o dia 22/02/08.

A pesquisa tem por objetivo investigar o trabalho e os riscos de adoecimento por ele provocado, em termos de representação do contexto de trabalho, exigências (físicas, cognitivas e afetivas), vivências e danos. Será aplicada a todos os empregados das áreas compartilhadas das Entidades Nacionais do Sistema Indústria, que tiverem acesso a computador.

Lembramos que trata-se de uma ação alinhada à Política de Educação Treinamento e Desenvolvimento - ETD, que pretende estimular seus participantes a desenvolverem pesquisas voltadas à aplicação no trabalho, com vistas ao desenvolvimento e aperfeiçoamento de projetos e processos, em sua área de atuação.

Desde já, agradecemos por sua participação e esclarecemos que os dados coletados serão tratados de forma responsável e, que preservarão o sigilo das informações fornecidas por seus participantes.

Agradecemos a colaboração!

\section{$X X X X X X X X X X X X X X X$}

Gerente Executiva de Recursos Humanos

Sistema Indústria (CNI, SESI, SENAI e IEL)

(61) XXXXXXXXX

Clique aqui para responder o questionário. 


\section{ANEXO A \\ Inventário de Trabalho e Riscos de Adoecimento - ITRA}

Essa pesquisa tem um duplo objetivo: (a) coletar informações sobre as dimensões do trabalho que constituem fatores de riscos para qualidade de vida no trabalho; e (b) subsidiar o planejamento de ações institucionais nos campos das condições, da organização e das relações socioprofissionais de trabalho. É uma pesquisa sob a responsabilidade técnico-cientifica dos grupos "Grupo de Estudos e Pesquisas em Ergonomia Aplicada ao Setor Público - ErgoPublic" e "Grupo de Estudos e Pesquisas em Saúde e Trabalho - GEPSAT" da Universidade de Brasília - UnB.

As informações prestadas por você são sigilosas e serão analisadas em conjunto com as informações fornecidas por seus colegas.

É um questionário composto de quatro instrumentos e algumas questões abertas. Ao responder o questionário, fique atento para as instruções de respostas.

Sua participação é fundamental 
Leia os itens abaixo e escolha a alternativa que melhor corresponde à avaliação que você faz do seu contexto de trabalho.

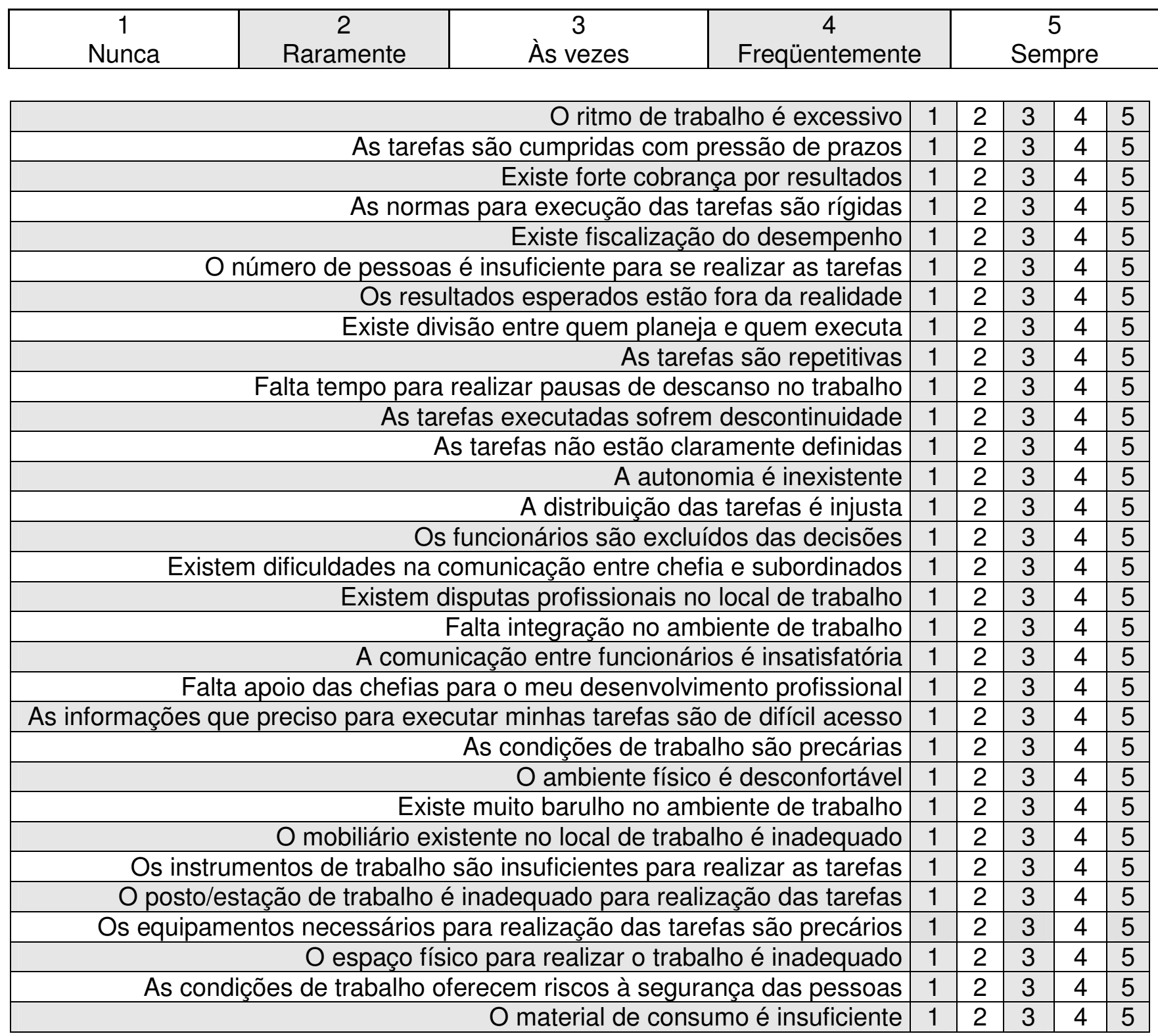

Agora escolha a alternativa que melhor corresponde à avaliação que você faz das exigências decorrentes do seu contexto de trabalho.

\begin{tabular}{|c|c|c|c|c|}
\hline 1 & 2 & 3 & 4 & 5 \\
nada exigido & pouco exigido & mais ou menos exigido & bastante exigido & $\begin{array}{c}5 \\
\text { totalmente } \\
\text { exigido }\end{array}$ \\
\hline
\end{tabular}

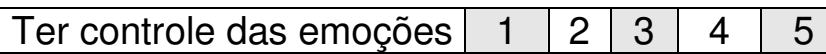

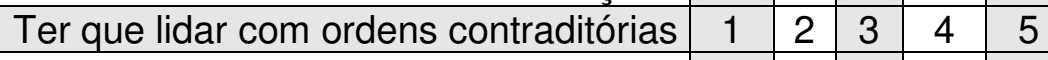

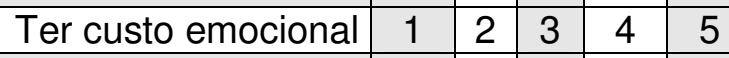

\begin{tabular}{|l|l|l|l|l|l|} 
Ser obrigado a lidar com a agressividade dos outros & 1 & 2 & 3 & 4 & 5 \\
\hline
\end{tabular} 


\begin{tabular}{|c|c|c|c|c|c|c|c|}
\hline \multicolumn{2}{|c|}{ Disfarçar os sentimentos } & 1 & 2 & 3 & 4 & 5 \\
\hline \multicolumn{2}{|c|}{\begin{tabular}{c} 
Ser obrigado a elogiar as pessoas \\
\hline 1
\end{tabular}} & $\begin{array}{c}4 \\
3\end{array}$ & 4 & 5 \\
\hline nada exigido & pouco exigido & mais ou menos exigido & bastante exigido & \multicolumn{2}{|c|}{$\begin{array}{c}5 \\
\text { totalmente } \\
\text { exigido }\end{array}$} \\
\hline
\end{tabular}

\begin{tabular}{|r|c|c|c|c|c|}
\hline Ser obrigado a ter bom humor & 1 & 2 & 3 & 4 & 5 \\
\hline Ser obrigado a cuidar da aparência física & 1 & 2 & 3 & 4 & 5 \\
\hline Ser bonzinho com os outros & 1 & 2 & 3 & 4 & 5 \\
\hline Transgredir valores éticos & 1 & 2 & 3 & 4 & 5 \\
\hline Ser submetido a constrangimentos & 1 & 2 & 3 & 4 & 5 \\
\hline Sesenvoligado a sorrir & 1 & 2 & 3 & 4 & 5 \\
\hline Ter que resolver problemas & 1 & 2 & 3 & 4 & 5 \\
\hline Ser obrigado a lidar com imprevistos & 1 & 2 & 3 & 4 & 5 \\
\hline Fazer previsão de acontecimentos & 1 & 2 & 3 & 4 & 5 \\
\hline Usar a visão de forma contínua & 1 & 2 & 3 & 4 & 5 \\
\hline Usar a memória & 1 & 2 & 3 & 4 & 5 \\
\hline Ter desafios intelectuais & 1 & 2 & 3 & 4 & 5 \\
\hline Fazer esforço mental & 1 & 2 & 3 & 4 & 5 \\
\hline Ter concentração mental & 1 & 2 & 3 & 4 & 5 \\
\hline Usar a criatividade & 1 & 2 & 3 & 4 & 5 \\
\hline Usar a força física & 1 & 2 & 3 & 4 & 5 \\
\hline 3 & 4 & 5 \\
\hline Usar os braços de forma contínua & 1 & 2 & 3 & 4 & 2 \\
\hline Ficar em posição curvada & 1 & 2 & 3 & 4 & 5 \\
\hline Caminhar & 1 & 2 & 3 & 4 & 5 \\
\hline Ser obrigado a ficar em pé & 1 & 2 & 3 & 4 & 5 \\
\hline Fer que manusear objetos pesados & 1 & 2 & 3 & 4 & 5 \\
\hline Fazer esforço físico & 1 & 2 & 3 & 4 & 5 \\
\hline Usar as pernas de forma contínua & 1 & 2 & 3 & 4 & 5 \\
\hline & 2 & 3 & 4 & 5 \\
\hline
\end{tabular}

Avaliando o seu trabalho nos últimos seis meses, marque o número de vezes em que ocorrem as seguintes vivências.

\begin{tabular}{|c|c|c|c|c|c|c|}
\hline $\begin{array}{c}0 \\
\text { Nenhuma } \\
\text { Vez }\end{array}$ & $\begin{array}{c}1 \\
\text { Uma } \\
\text { Vez }\end{array}$ & $\begin{array}{c}2 \\
\text { Duas } \\
\text { Vezes }\end{array}$ & $\begin{array}{c}3 \\
\text { Três } \\
\text { Vezes }\end{array}$ & $\begin{array}{c}4 \\
\text { Quatro } \\
\text { Vezes }\end{array}$ & $\begin{array}{c}5 \\
\text { Cinco } \\
\text { Vezes }\end{array}$ & $\begin{array}{c}6 \\
\text { Seis ou mais } \\
\text { Vezes }\end{array}$ \\
\hline
\end{tabular}

\begin{tabular}{|r|c|c|c|c|c|c|c|}
\hline Liberdade com a chefia para negociar o que precisa & 0 & 1 & 2 & 3 & 4 & 5 & 6 \\
\hline Liberdade para falar sobre o meu trabalho com os colegas & 0 & 1 & 2 & 3 & 4 & 5 & 6 \\
\hline Solidariedade entre os colegas & 0 & 1 & 2 & 3 & 4 & 5 & 6 \\
\hline Confiança entre os colegas & 0 & 1 & 2 & 3 & 4 & 5 & 6 \\
\hline Liberdade para expressar minhas opiniões no local de trabalho & 0 & 1 & 2 & 3 & 4 & 5 & 6 \\
\hline Liberdade para usar a minha criatividade & 0 & 1 & 2 & 3 & 4 & 5 & 6 \\
\hline Ciberdade para falar sobre o meu trabalho com as chefias & 0 & 1 & 2 & 3 & 4 & 5 & 6 \\
\hline Coração entre os colegas & 0 & 1 & 2 & 3 & 4 & 5 & 6 \\
\hline Satisfação & 0 & 1 & 2 & 3 & 4 & 5 & 6 \\
\hline Motivação & 0 & 1 & 2 & 3 & 4 & 5 & 6 \\
\hline Orgulho pelo que faço & 0 & 1 & 2 & 3 & 4 & 5 & 6 \\
\hline 0 Bem-estar & 0 & 1 & 2 & 3 & 4 & 5 & 6 \\
\hline
\end{tabular}




\begin{tabular}{|c|c|c|c|c|c|c|c|c|c|c|c|c|}
\hline \multicolumn{6}{|c|}{ Realização profissional } & 0 & 1 & 2 & 3 & 4 & 5 & 6 \\
\hline \multicolumn{6}{|c|}{ Valorização } & 0 & 1 & 2 & 3 & 4 & 5 & 6 \\
\hline \multicolumn{6}{|c|}{ Reconhecimento } & 0 & 1 & 2 & 3 & 4 & 5 & 6 \\
\hline $\begin{array}{c}0 \\
\text { Nenhuma }\end{array}$ & $\begin{array}{c}1 \\
\text { Uma }\end{array}$ & $\begin{array}{c}2 \\
\text { Duas }\end{array}$ & $\begin{array}{c}3 \\
\text { Três }\end{array}$ & $\begin{array}{c}4 \\
\text { Quatro }\end{array}$ & & 5 & & & Seis & $\begin{array}{c}6 \\
\text { ou }\end{array}$ & mai & \\
\hline
\end{tabular}

\begin{tabular}{|r|c|c|c|c|c|c|c|}
\hline Identificação com as minhas tarefas & 0 & 1 & 2 & 3 & 4 & 5 & 6 \\
\hline Gratificação pessoal com as minhas atividades & 0 & 1 & 2 & 3 & 4 & 5 & 6 \\
\hline Esgotamento emocional & 0 & 1 & 2 & 3 & 4 & 5 & 6 \\
\hline Estresse & 0 & 1 & 2 & 3 & 4 & 5 & 6 \\
\hline Insatisfação & 0 & 1 & 2 & 3 & 4 & 5 & 6 \\
\hline Sobrecarga & 0 & 1 & 2 & 3 & 4 & 5 & 6 \\
\hline Frustração & 0 & 1 & 2 & 3 & 4 & 5 & 6 \\
\hline Insegurança & 0 & 1 & 2 & 3 & 4 & 5 & 6 \\
\hline Medo & 0 & 1 & 2 & 3 & 4 & 5 & 6 \\
\hline Falta de reconhecimento do meu esforço & 0 & 1 & 2 & 3 & 4 & 5 & 6 \\
\hline Falta de reconhecimento do meu desempenho & 0 & 1 & 2 & 3 & 4 & 5 & 6 \\
\hline Desvalorização & 0 & 1 & 2 & 3 & 4 & 5 & 6 \\
\hline Indignação & 0 & 1 & 2 & 3 & 4 & 5 & 6 \\
\hline Inutilidade & 0 & 1 & 2 & 3 & 4 & 5 & 6 \\
\hline Desqualificação & 0 & 1 & 2 & 3 & 4 & 5 & 6 \\
\hline Injustiça & 0 & 1 & 2 & 3 & 4 & 5 & 6 \\
\hline Discriminação & 0 & 1 & 2 & 3 & 4 & 5 & 6 \\
\hline
\end{tabular}

Os itens, a seguir, tratam dos tipos de problemas físicos, psicológicos e sociais que você avalia como causados, essencialmente, pelo seu trabalho. Marque o número que melhor corresponde à frequiência com a qual eles estiveram presentes na sua vida nos últimos seis meses.

\begin{tabular}{|c|c|c|c|c|c|c|}
\hline 0 & 1 & 2 & 3 & 4 & 5 & 6 \\
$\begin{array}{c}\text { Nenhuma } \\
\text { Vez }\end{array}$ & Uma & Duas & Três & Quatro & Cinco & Seis Vezes \\
\hline
\end{tabular}

\begin{tabular}{|r|c|c|c|c|c|c|c|}
\hline Dores no corpo & 0 & 1 & 2 & 3 & 4 & 5 & 6 \\
\hline Dores nos braços & 0 & 1 & 2 & 3 & 4 & 5 & 6 \\
\hline Dor de cabeça & 0 & 1 & 2 & 3 & 4 & 5 & 6 \\
\hline Distúrbios respiratórios & 0 & 1 & 2 & 3 & 4 & 5 & 6 \\
\hline Distúrbios digestivos & 0 & 1 & 2 & 3 & 4 & 5 & 6 \\
\hline Dores nas costas & 0 & 1 & 2 & 3 & 4 & 5 & 6 \\
\hline Distúrbios auditivos & 0 & 1 & 2 & 3 & 4 & 5 & 6 \\
\hline Alterações do apetite & 0 & 1 & 2 & 3 & 4 & 5 & 6 \\
\hline Distúrbios na visão & 0 & 1 & 2 & 3 & 4 & 5 & 6 \\
\hline Alterações do sono & 0 & 1 & 2 & 3 & 4 & 5 & 6 \\
\hline Dores nas pernas & 0 & 1 & 2 & 3 & 4 & 5 & 6 \\
\hline Distúrbios circulatórios & 0 & 1 & 2 & 3 & 4 & 5 & 6 \\
\hline relação aos colegas & 0 & 1 & 2 & 3 & 4 & 5 & 6 \\
\hline Insensibilidade em riculdades nas relações fora do trabalho & 0 & 1 & 2 & 3 & 4 & 5 & 6 \\
\hline Vontade de ficar sozinho & 0 & 1 & 2 & 3 & 4 & 5 & 6 \\
\hline Conflitos nas relações familiares & 0 & 1 & 2 & 3 & 4 & 5 & 6 \\
\hline Agressividade com os outros & 0 & 1 & 2 & 3 & 4 & 5 & 6 \\
\hline
\end{tabular}




\begin{tabular}{|c|c|c|c|c|c|c|c|c|c|c|c|c|}
\hline \multicolumn{6}{|c|}{ Dificuldade com os amigos } & 0 & 1 & 2 & 3 & 4 & 5 & 6 \\
\hline \multicolumn{6}{|c|}{ Impaciência com as pessoas em geral } & 0 & 1 & 2 & 3 & 4 & 5 & 6 \\
\hline \multicolumn{6}{|c|}{ Amargura } & 0 & 1 & 2 & 3 & 4 & 5 & 6 \\
\hline \multicolumn{6}{|c|}{ Sensação de vazio } & 0 & 1 & 2 & 3 & 4 & 5 & 6 \\
\hline $\begin{array}{c}0 \\
\text { Nenhuma } \\
\text { Vez }\end{array}$ & $\begin{array}{c}1 \\
\text { Uma } \\
\text { Vez }\end{array}$ & $\begin{array}{c}2 \\
\text { Duas } \\
\text { Vezes }\end{array}$ & $\begin{array}{c}3 \\
\text { Três } \\
\text { Vezes }\end{array}$ & $\begin{array}{c}4 \\
\text { Quatro } \\
\text { Vezes }\end{array}$ & \multicolumn{3}{|c|}{$\begin{array}{c}5 \\
\text { Cinco } \\
\text { Vezes }\end{array}$} & \multicolumn{5}{|c|}{$\begin{array}{c}6 \\
\text { Seis Vezes }\end{array}$} \\
\hline
\end{tabular}

\begin{tabular}{|r|c|c|c|c|c|c|c|}
\hline Sentimento de desamparo & 0 & 1 & 2 & 3 & 4 & 5 & 6 \\
\hline Mau-humor & 0 & 1 & 2 & 3 & 4 & 5 & 6 \\
\hline Vontade de desistir de tudo & 0 & 1 & 2 & 3 & 4 & 5 & 6 \\
\hline Tristeza & 0 & 1 & 2 & 3 & 4 & 5 & 6 \\
\hline Irritação com tudo & 0 & 1 & 2 & 3 & 4 & 5 & 6 \\
\hline Sensação de abandono & 0 & 1 & 2 & 3 & 4 & 5 & 6 \\
\hline Dúvida sobre a capacidade de fazer as tarefas & 0 & 1 & 2 & 3 & 4 & 5 & 6 \\
\hline Solidão & 0 & 1 & 2 & 3 & 4 & 5 & 6 \\
\hline
\end{tabular}

1) O que é, para você, Qualidade de Vida no Trabalho?

2) Quais ações você considera prioritárias?

Seus comentários/sugestões sobre esta pesquisa:

\section{Para finalizar, preencha os seguintes dados complementares:}

Idade: anos

Gênero: ( ) Masculino ( ) Feminino

Escolaridade:
( ) Até segundo Grau
( ) Superior Incompleto
( ) Superior
( ) Pós-graduação

Estado Civil:

Cargo atual: 
Lotação:

Tempo de serviço na instituição: anos

Tempo de serviço no cargo: anos

Participou do último exame médico: Sim ( ) Não ( )

Afastamentos do trabalho por problema de saúde relacionado ao trabalho no ano:

Nenhum ( )

Entre 1 e $3($ )

Mais de 3

Obrigado Pela sua Participação! 